\title{
Impact of Wind and Solar Generation on the Italian Zonal Electricity Price
}

\author{
Mahmood Hosseini Imani *(D), Ettore Bompard (D), Pietro Colella (D) and Tao Huang (D) \\ Department of Energy, Politecnico di Torino, 10129 Torino, Italy; ettore.bompard@polito.it (E.B.); \\ pietro.colella@polito.it (P.C.); tao.huang@polito.it (T.H.) \\ * Correspondence: mahmood.hosseiniimani@polito.it
}

Citation: Hosseini Imani, M.; Bompard, E.; Colella, P.; Huang, T. Impact of Wind and Solar Generation on the Italian Zonal Electricity Price. Energies 2021, 14, 5858. https:// doi.org/10.3390/en14185858

Academic Editor: Ricardo J. Bessa

Received: 5 July 2021

Accepted: 14 September 2021

Published: 16 September 2021

Publisher's Note: MDPI stays neutral with regard to jurisdictional claims in published maps and institutional affiliations.

Copyright: (c) 2021 by the authors. Licensee MDPI, Basel, Switzerland. This article is an open access article distributed under the terms and conditions of the Creative Commons Attribution (CC BY) license (https:// creativecommons.org/licenses/by/ $4.0 /)$.

\begin{abstract}
This paper assesses the impact of increasing wind and solar power generation on zonal market prices in the Italian electricity market from 2015 to 2019, employing a multivariate regression model. A significant aspect to be considered is how the additional wind and solar generation brings changes in the inter-zonal export and import flows. We constructed a zonal dataset consisting of electricity price, demand, wind and solar generation, net input flow, and gas price. In the first and second steps of this study, the impact of additional wind and solar generation that is distributed across zonal borders is calculated separately based on an empirical approach. Then, the Merit Order Effect of the intermittent renewable energy sources is quantified in every six geographical zones of the Italian day-ahead market. The results generated by the multivariate regression model reveal that increasing wind and solar generation decreases the daily zonal electricity price. Therefore, the Merit Order Effect in each zonal market is confirmed. These findings also suggest that the Italian electricity market operator can reduce the National Single Price by accelerating wind and solar generation development. Moreover, these results allow to generate knowledge advantageous for decision-makers and market planners to predict the future market structure.
\end{abstract}

Keywords: inter-zonal exchange; Italian wholesale power market; Merit Order Effect; multivariate regression; solar power integration; wind power integration

\section{Introduction}

Over the past decades, with growing concern about increasing concentrations of atmospheric pollutants and reducing dependency on fossil fuels, the generation of energy from renewable energy sources (RESs) has become a priority worldwide. By establishing the Directive 2009/28/EC, a framework for supporting renewable energy in European countries, the legal framework for promoting renewable electricity has vastly improved [1].

By developing technologies and national support schemes, electricity production from RESs in Italy has developed rapidly. National support schemes, including the Green Certificates Scheme and Conto Energia, mainly support the production of electricity from renewable sources [2-4].

The development of RESs generation, particularly wind and solar, has given rise to many economic and technological challenges to the power grid. In the economic aspect, the impact of RES participation on the designation of wholesale electricity prices has gained more attention from policymakers, market participants, and operators [5].

In economic research in the context of RES production, evaluating and quantifying the revenue and costs of additional renewable electricity injected into the power grid and its effect on spot prices are essential challenges.

Spot prices are designated as a function of demand and supply. The demand curve represents the relationship between price and quantity for a specific product. The supply curve, the so-called merit order, is obtained by sorting the provider bids according to ascending orders of marginal price, which indicates the relationship between price and 
quantity of product [6]. The point of intersection between the supply and the demand curves defines the spot prices, i.e., the market-clearing price. The feed-in of RESs-wind and solar generation-with low or near zero marginal price affects the intersection point of the merit order with the demand. Consequently, any increase in wind and solar generation with zero pricing bids added to the generation mix results in a shift of the supply curve to the right.

The increment in wind and solar results in pushing more expensive generations out of the electricity market. Thus, changes in the supply curve and generation mix can lead to changes in the price. This phenomenon is the so-called Merit Order Effect (MOE) [7-9].

In this paper, we apply a multivariate regression model to each zonal market of the Italian electricity market over the period 2015-2019, carrying out three different estimations. In the first and second estimations, the impact of increasing wind and solar electricity generation on the net input flow (in the zone $i$ at time $t$, the net input flow is defined as inflows subtracted from outflows $\left(\sum\right.$ Import $_{t z}-\sum$ Export $\left._{t z}\right)$ ) in each zone is extensively investigated using hourly data. Then, in the third estimation, the merit order effect of wind and solar generation is quantified based on the developed empirical approach in [10-12].

In this regard, we use a daily average of hourly zonal market data to estimate econometric models that relate the zonal electricity price to the electricity produced by wind and solar. In addition, we use natural gas (NG) price as a significant factor that influences the electricity price. The NG price dataset is taken from the Spot Gas Market (MGP-GAS) [4].

We feel that this investigation on the Italian electricity market closes a significant research gap for quite a few reasons. First, the study provides a comprehensive overview of the impact of an increase in wind and solar production on the net input flow of each geographical zone separately, which generates principal knowledge advantageous for decision-makers to predict the future market structure. Second, the results can be extrapolated considering various assumptions on expanding intermittent RESs in different geographical zones. Third, the Italian electricity market zones have different environmental and territorial characteristics, resulting in different potentials of RESs. Finally, the models of this study can be utilized in other large interconnected markets that have high renewable shares in several regions.

The paper is structured as follows: In Section 2, we review the literature on the merit order effect in the various countries. Section 3 briefly explains the Italian electricity market and inter-zonal pricing mechanism and a statistical summary of zonal price, zonal demand, and intermittent RESs penetration in the Italian electricity market. Section 4 describes the methodology and econometric models. Section 5 provides the model results. Finally, the paper is concluded in Section 6.

\section{Literature Review}

In recent years, numerous studies have evaluated the effects of wind and solar generations on electricity market prices (i.e., the MOE) in various countries. These studies include assessments of the MOE, evaluations of specific support mechanisms, and comparisons of the performance of various support schemes. Although a precise estimation of the MOE depends on different factors, e.g., market conditions and generation mix, these studies take advantage of available real historical data regarding electricity prices, electricity demand, and RES production.

Most of this literature investigates the MOE effect by applying relatively similar regression methods. The only difference between these models is due to market structure, availability of data, and energy mix differences in different countries.

In Spain, by using a multivariate regression model on the daily historical data of the electricity market between 2005 and 2010, a marginal increase of $1 \mathrm{GW}$ of renewables generation results in an average of an almost $2 € / M W h$ decrease in the spot electricity price [10]. The study explains that the calculated MOE has a decreasing trend despite the increasing penetration of RESs to the Spanish system. The critical reasons for this decline are the rise of dispatched natural gas power plants due to lower fuel prices and the large 
market power that these plants exert to compensate for the loss of revenue caused by the increasing share of RESs. Similarly, in the case of Portugal, the existence of the MOE from wind power is confirmed in the long period from 2011 to 2019 [13]. The authors conclude that increases in the generation from wind farms and photovoltaic power plants may prevent high marginal cost power plants from setting the electricity market price. In addition, they find that electricity production from wind power decreases the price of electricity but increases its volatility.

Studies also exist for the electricity market in Germany $[12,14,15]$. Although employing different models and approaches, the estimated results are very similar. For instance, in [14], an empirical approach is employed to analyze the specific impacts of wind and solar generation on the electricity market between 2008 and 2016. The study reveals that by increasing $1 \mathrm{GW}$ of wind and solar generation, the MOE ranges from 0.97 to 2.27€/MWh and from 0.84 to $1.37 € / \mathrm{MWh}$, respectively.

The Nord Pool electricity market is one of the most interesting case studies to estimate the impact of RESs on the wholesale electricity price due to the existence of multiple pricing areas, among which Western Denmark's area spot price (DK1), Nord Pool market-clearing price, and Finland's (FI) area spot price can be considered the main ones [16]. The study in [17] shows that a marginal increase of 1 TWh of DK RESs results in an annual average of $8.33 € /$ MWh decrease in the Danish spot price in 2015. In addition, it demonstrates how unilateral decisions at the national level related to the increment or decline in selected electricity generation sources can significantly impact market prices across national borders in the Nordic area.

In [18], the MOE in Ireland is investigated. The study employs a broad set of hourly input variables, e.g., demand, wind generation, and fossil fuel prices in 2009. The empirical applications show that by increasing $1 \mathrm{GW}$ of wind production, the electricity price falls by $9.9 € / \mathrm{MWh}$.

The effects of wind and solar generation in the Turkish electricity market are instead discussed in [19]. The regression model and the welfare analysis reveal that the MOE is higher when demand is low, and different RESs technologies have a different impact on electricity price.

In [20], the authors use multivariate regression models on the Midcontinent Independent System Operator (MISO), as the second-largest organized competitive wholesale electricity market in the United States, to identify the impact of increased wind generation on wholesale electricity prices between 2008 and 2016. The study's outcome reveals that an extra $100 \mathrm{MW}$ of wind generation decreased the electricity price by $0.33 \$ / \mathrm{MWh}$ from 2008 to 2011, 0.22\$/MWh from 2011 to 2013, and 0.15\$/MWh from 2013 to 2016. The declining trend over time is explained by the long-term shifts in the supply and demand dynamics in the MISO and by the alternation in the market structures that are compatible with RESs. In [21], the authors adopt a regression model considering hourly electricity prices between 2006 and 2011 to assess the MOE in Ontario. The study concludes that the MOE is different considering congestion in different zones. It also points out that incorrect economic incentives could be given to wind companies in case the MOE is not carefully evaluated.

The Australian case study is analyzed through a regression model that needs daily input data, including wind, solar, demand, and NG price, to quantify the total MOE [22]. The authors conclude that between 2010 and 2018, an additional GW of dispatched wind and solar capacity decreased the electricity price by 11 AUD/MWh and 14 AUD/MWh, respectively.

Time-series regression analyses are adopted in [8] to analyze the merit-order effect in the Italian power market over the period 2009-2013. The authors exploit the multivariate regression model with explanatory variables that include the daily mean of the hourly national electricity demand, the daily mean of wind and solar generation (intermittent RESs), and the daily spot price of NG. A marginal increase of $1 \mathrm{GWh}$ in the hourly average of daily wind and solar generation leads to $4.2 € / \mathrm{MWh}$ and $2.3 € / \mathrm{MWh}$ daily wholesale 
electricity price reductions, respectively. The main issue of the work is that only the national impact of wind and solar generation is evaluated, although Italy adopts an inter-zonal pricing mechanism that splits the national electricity market into different zones. According to our knowledge, the impact of wind and solar generation on the Italian zonal market price has not been addressed in previous research.

\section{Italian Electricity Market}

\subsection{Introduction of the Italian Electricity Market}

The Italian wholesale electricity market (IPEX (Italian Power Exchange)) was started in April 2004 and has become open for exchange since January 2005 with the liberalization of demand side bidding [23]. The Electricity Market consists of the Spot Electricity Market (MPE) and the Forward Electricity Market (MTE). In this work, only the MPE is considered. It consists of the Day-Ahead Market (MGP), Intra-Day Market (MI), Daily Products Market (MPEG), and Ancillary Services Market (MSD).

To optimize and maintain the Italian electricity system, a zonal market model was adopted. Italy was divided into 13 foreign virtual zones, six geographical zones, and one pole of limited production (national virtual zone). The location of the six geographical zones of the IPEX is shown in Figure 1 [4].

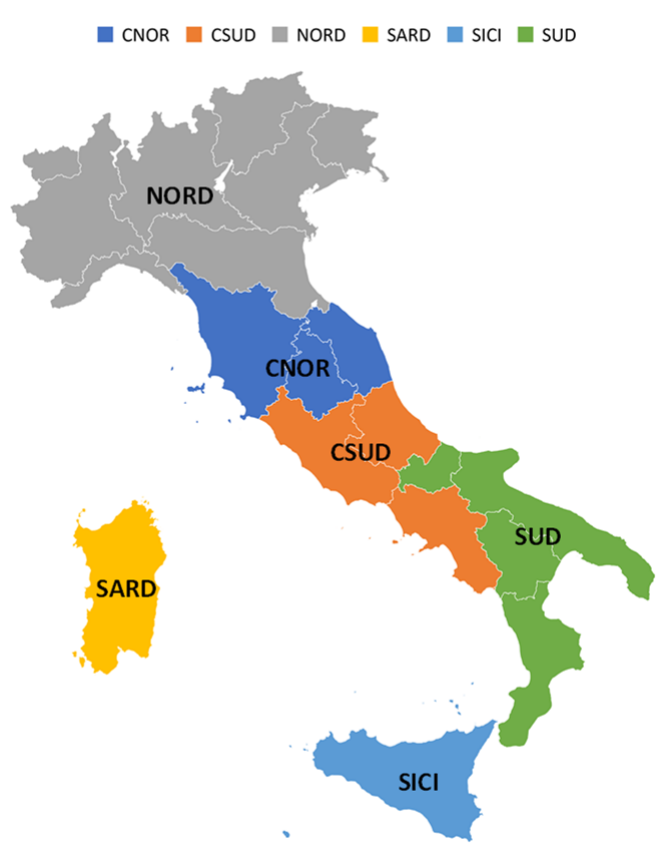

Figure 1. Map of the Italian geographic zone (starting from 1 January 2021, Calabria is operated as a new geographical zone. The introduction of the Calabria as a geographical zone brings the number of geographical zones from 6 to 7 zones) [4].

\subsection{Price Formation Mechanism}

In the MGP, the submissions of market participants occur between the ninth day before the day of physical delivery (opens at 8 a.m.) and the day before the day of delivery (closes at 12 p.m.) [24].

In the MGP, the electricity price formation follows an iterative process. In the first step, the supply and demand curves are constructed based on the merit order criterion by collecting all the supply and demand bids from all the zones. In the second step, the interzonal transmission line limits are checked. If the interzonal flows are within the line limits, the market-clearing price is identified by the intersection of the demand and supply curves. Vice-versa, if at least some constraint is violated, each congested transmission line separates the zones into two sub-markets with their merit order and demand curves. The 
previously mentioned step is repeated in each sub-market until each separated market supply and demand plan respects all network constraints across zones [4].

After obtaining the zonal price, an average price defined as the National Single Price (PUN), weighted for total purchases and net purchases for pumped-storage units and for purchases by neighboring countries' zones, is adopted to charge the demands [4].

\subsection{Descriptive Statistics}

In this section, to have a better overview, a statistical summary of zonal price, zonal demand, zonal wind and, solar penetration is presented for the years 2015-2019.

\subsubsection{Zonal Price and Demand}

The general trend of the average zonal prices and zonal demand for 2015-2019 can be seen in Figures 2 and 3, respectively.

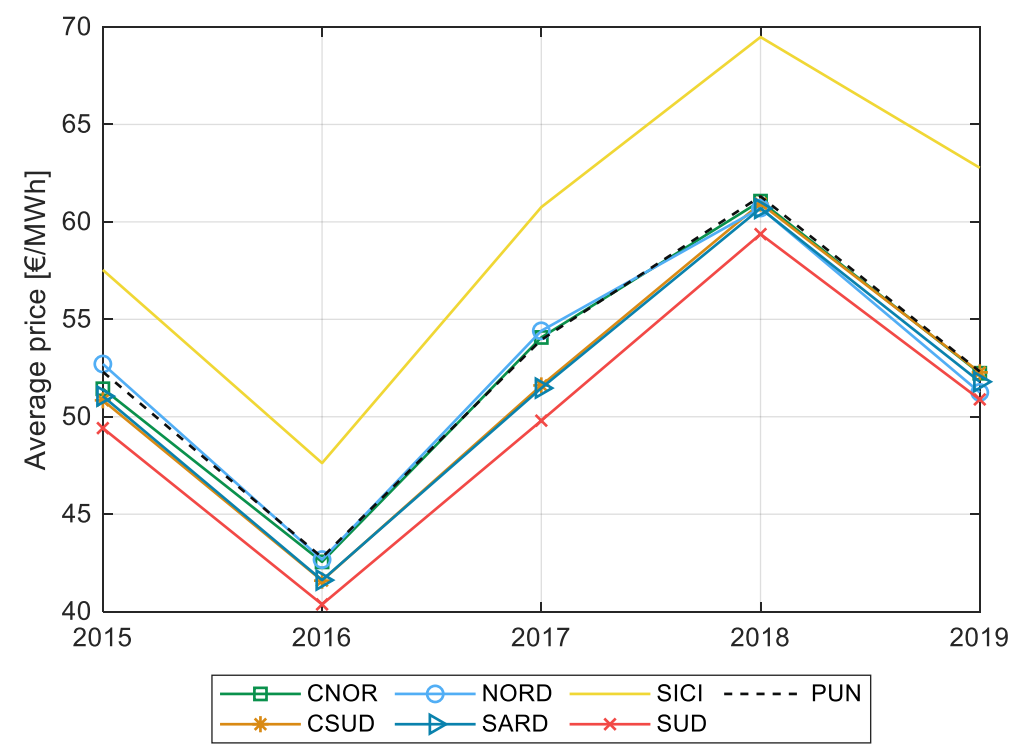

Figure 2. Average zonal and national electricity price trend for the period 2015-2019 [4].

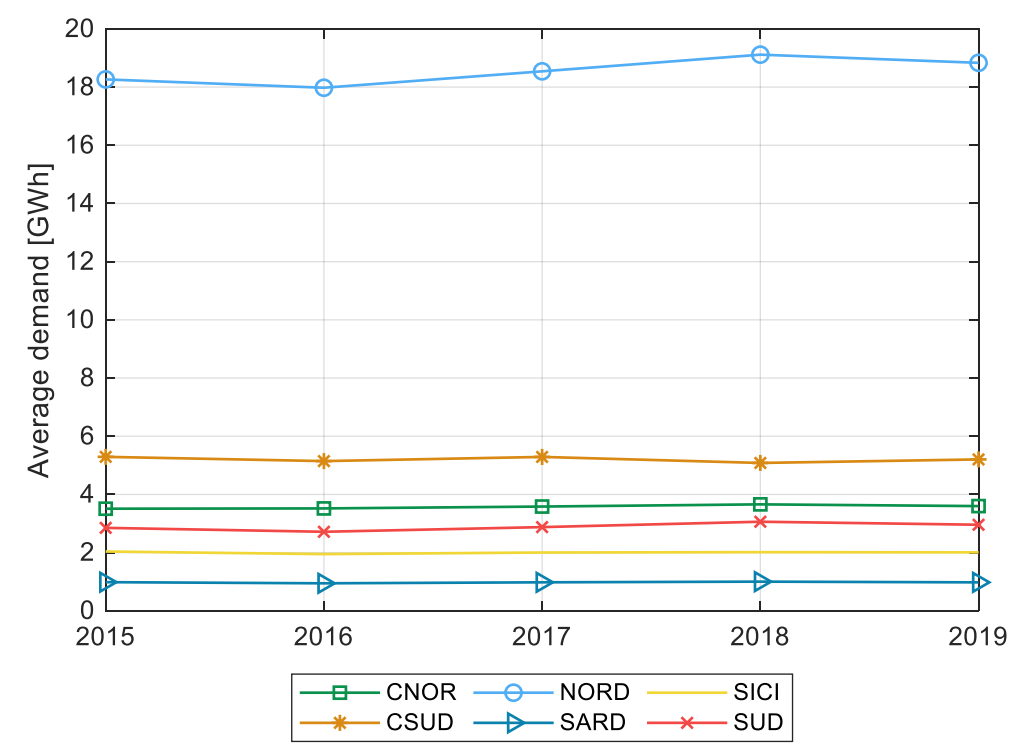

Figure 3. Average zonal demand trend for the period 2015-2019 [25].

The zonal and national price plots reveal that the PUN almost follows the price pattern of NORD and CNOR, as the load of the region accounts for around $56 \%$ of the overall 
Italian load [25]. Between 2015 to 2019, the transmission line between SICI and SUD zones was congested in about $55 \%$ of the market hours (nearly $50 \%$ from SUD to SICI); hence the zonal price in SICI is higher than in the other zones [4].

In 2016, PUN recorded an 18.2\% decrease compared to 2015. This significant decline was due to the robust downward trend of fuel costs. Compared to the previous year, Brent oil and gas prices at PSV declined by $16.5 \%$ and $28.4 \%$, respectively. In 2017 the electricity prices in Italy were affected by increments of fuel prices and seasonal problems associated with the French national power plants, e.g., the reduced availability of French nuclear plants. As a result, the imported flow from France decreased. Thus, the shortage was compensated by the expensive Italian thermoelectric supply. These problems triggered the high prices recorded in Italy. In 2018, PUN reached its highest since 2014. The sharp rise in electricity prices was closely connected to the fuel markets. In the last four years, the price of fuel oil, gas at PSV, and Gasoil recorded growth, namely $+33 \%,+23 \%$, and $31 \%$, respectively. Starting from October 2018, Brent oil and gas prices had a progressive reduction. This decline was consolidated in 2019. As a result of the reduction in fuel prices, Italian electricity prices also fell [4].

Based on Figure 3, in terms of average demand, NORD had the highest average load than other geographical zones in Italy between 2015 and 2019. The demand gap was relatively large even if it is compared to the second-highest load, CSUD.

\subsubsection{Wind and Solar Penetration}

This section is devoted to describing wind and solar penetration (percentage of demand covered by wind or solar energy) in each geographical zone from 2015 to 2019 (Figure 4a). Solar penetration in SUD was far higher than in any other market zone in the MGP. Total solar power production in SUD was $4.2 \mathrm{TWh}$, equivalent to $16.42 \%$ of SUD's electricity consumption in 2019 . This fraction was reported to be lower than $17.86 \%$ in 2017 [25].

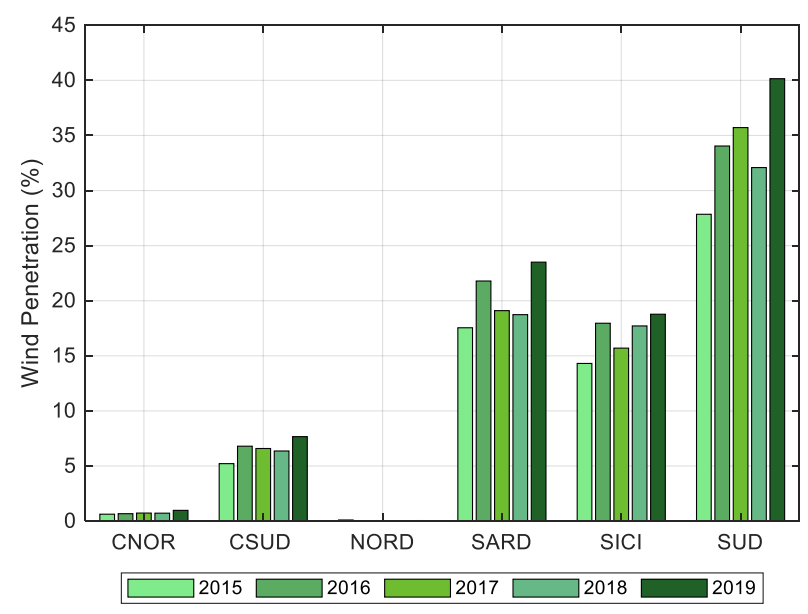

(a)

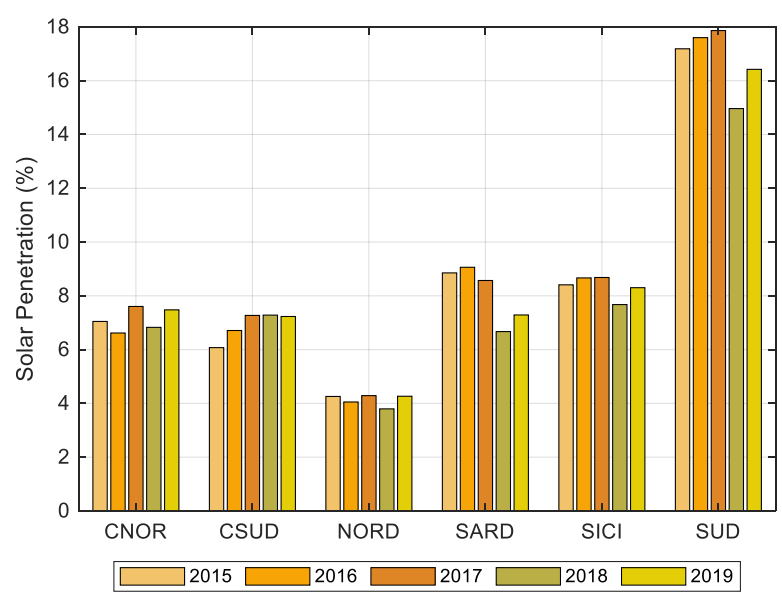

(b)

Figure 4. Wind (a) and solar (b) penetration in each zone; 2015 to 2019 [25].

Thanks to some environmental and territorial characteristics of sites such as windiness, orography, and accessibility, more wind power plants were installed in the south of Italy. In this regard, wind penetration in the south region, e.g., is far higher than in the north part, namely NORD and CNOR.

\section{Methodology and Data}

Wind and solar generation have an impact on the Italian zonal electricity prices. We implemented a multivariate regression model to estimate the average effect of marginal changes in wind and solar generation on Italian zonal electricity prices for 2015-2019. 
The data, including electricity and NG prices, were taken from Gestore dei Mercati Energetici (GME) [4]. In addition, the RESs and load consumption data were collected from ENTSO-e [25].

It is worth mentioning that there exists another catalog of the method to calculate the effect of increasing RESs or other zero/low marginal-cost generation on the power market, e.g., recreating and clearing the market in the merit order in each hour for the study period and making statistics over the market results. However, a significant drawback of this type of method is the high computational burden, since offers and bids of each market player change every hour. Therefore, these methods are not practical due to the impossibility of forecasting those bids and offers for each player every single hour. Therefore, we would need a different approach to quickly grasp the impact of different RES increments on the market price in different zones. Thus the empirical approach has gained much attention, among which the multivariate regression model we adopt in this paper is most popular in the literature $[8-12,14,15,20,22,26]$.

We briefly explain the preliminary tests of the dataset in Section 3.1. In Section 3.2 detailed information on the multivariate regression model is provided. In Section 3.3, the post-processing tests, including Breusch-Pagan and Durbin-Watson, are described in detail.

A diagram of the simulation procedures is depicted in Figure 5. Assessment of the proposed methodology is conducted based on this diagram.

\subsection{Preliminary Test}

Before proceeding to estimate the model, we applied a preliminary test on the data. In particular, we carried out two tests: the Augmented Dickey-Fuller test (ADF), and the Variance Inflator Indicator (VIF), which are described in Sections 4.1.1 and 4.1.2.

\subsubsection{Augmented Dickey-Fuller Test}

We carried out the augmented Dickey-Fuller (ADF) on the time-series in each zone to identify unit-roots. This process is essential in this context because if a time series has a unit root, it shows a systematic pattern that is unpredictable [27]. The ADF test was selected to test the null hypothesis $\mathrm{H} 0$ that the series has a unit root against hypothesis $\mathrm{H} 1$ that the series is stationary. Based on the ADF test in level, in each year, some time series were nonstationary. Thus, we estimated the model in first differences $(I(1))[10,12]$. After taking the first difference, the time series was stationary (Appendix A, Tables A1-A6). Therefore, by estimating the first order, ordinary least squares (OLS) estimates was the correct approach.

\subsubsection{Variance Inflator Indicator}

When independent variables in a regression model are correlated, the multi-collinearity problem occurs. The variance inflator indicator (VIF) allows one to identify the existence of multi-collinearity that can cause a reduction in the precision of the outcome coefficients, which weakens the statistical power of the regression model. Thanks to the high collinearity, the generation of traditional sources and electricity demand cannot be jointly utilized as explanatory variables. Traditional thermal capacity covers the residual load. By ignoring the generation of traditional sources, the VIF test results indicated that the problem of multi-collinearity does not exist in our model. 


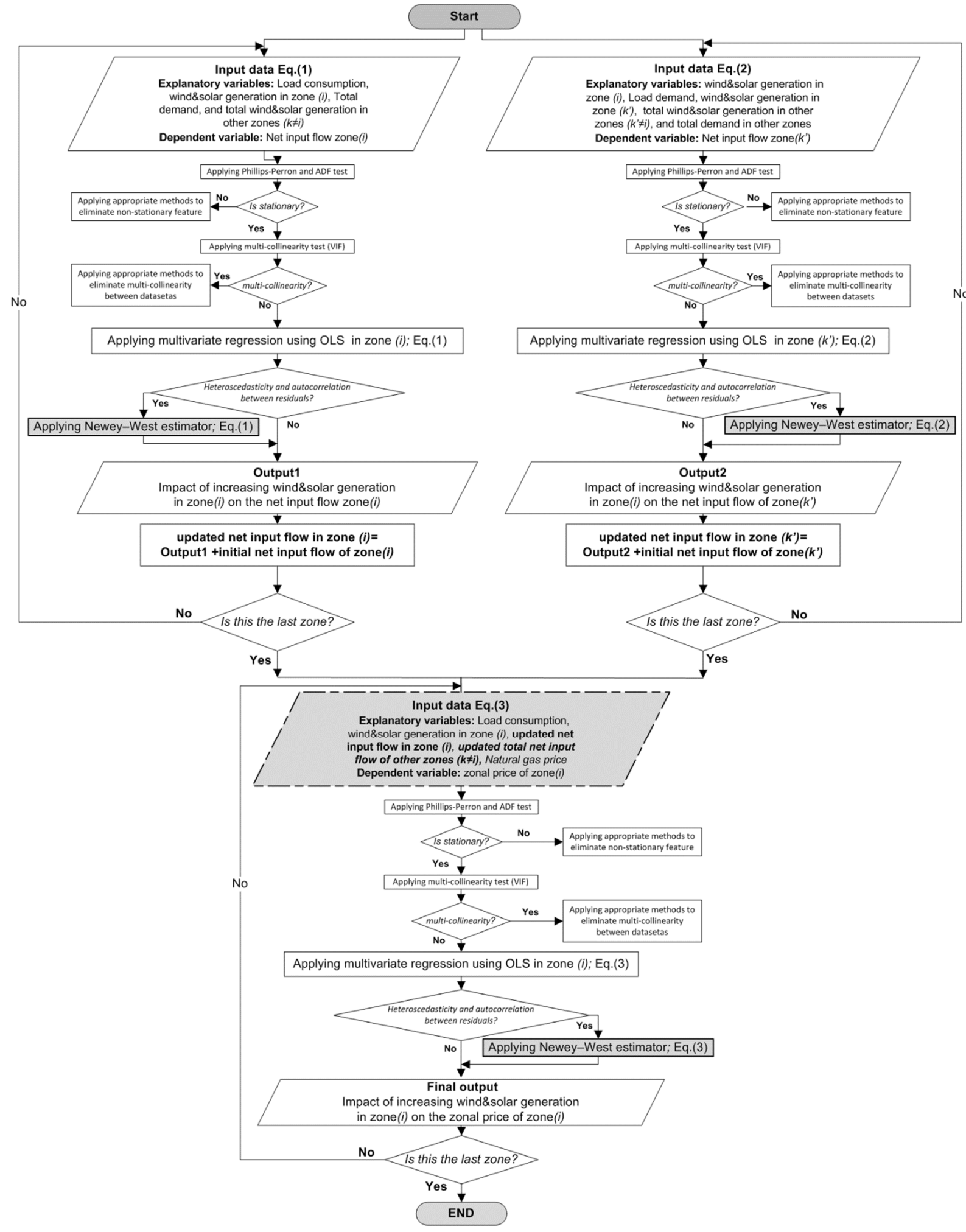

Figure 5. Diagram of the simulation procedures.

\subsection{Multivariate Regression Model}

Multivariate regression is a supervised machine learning algorithm involving one dependent variable and multiple independent variables for analysis. Multivariate regression tries to find a formula that can explain how factors in variables respond simultaneously to changes in others. 
This study used a multivariate regression model to estimate the average effect of marginal changes in wind and solar generation on Italian zonal electricity prices for individual years from 2015 to 2019. Zonal prices are directly associated with cross-zonal exchanges. Thus, capturing the impact of increasing wind and solar generation on each zonal net input flow can be more advantageous in analyzing the merit order effect in the Italian electricity market. In this regard, we built the model using the following steps:

$>$ First estimation: Estimating the impact of wind and solar generation on the net input flow of the given zone.

$>$ Second estimation: Estimating the impact of the wind and solar generation on the net input flow of the other zones.

$>$ Third estimation: Estimating the impact of wind and solar generation on the electricity price in the given zone.

In the first and second estimations, the net input flow of each zone is the dependent variable, and the explanatory variables are the zonal electricity demand, zonal electricity production from wind and solar, total wind and solar generation in other zones, and total electricity demand on the other zones.

In the third estimation, zonal electricity price is the dependent variable. The explanatory variables are the zonal demand for electricity, zonal electricity production from wind, zonal electricity production from solar, zonal net input flow, total other net input flow, and natural gas price. Due to the availability of the natural gas price in the daily sequence, the third estimation is estimated using the daily average dataset.

In this regard, the models were applied using the following strategy:

In the first step, in the zone $i$, we used multivariate regression Equation (1) to estimate the average effect of a marginal change in the wind and solar generation on the net input flow in the zone $i$,

$$
\begin{gathered}
\Delta \operatorname{NetIn}_{t, z i}=\eta+\theta_{1} \Delta \text { Wind }_{t, z i}+\theta_{2} \Delta \text { Solar }_{t, z i}+\theta_{3} \Delta \text { Demand }_{t, z i}+\theta_{4} \sum_{k=1, k \neq i}^{N Z} \Delta \text { Wind }_{t, z k}+\theta_{5} \sum_{k=1, k \neq i}^{N Z} \Delta \text { Solar }_{t, z k} \\
+\theta_{6} \sum_{k=1, k \neq i}^{N Z} \Delta \text { Demand }_{t, z k}+\theta_{7} D H_{t}+\theta_{8} D D_{t}+\theta_{9} D M_{t}+\varepsilon_{t, z}
\end{gathered}
$$

where $\varepsilon$ denotes the standard error term and $\Delta$ represents the first difference in variable.

The net input flow to the zone $i$ at time $t\left(\Delta N e t I n_{t, z i}\right)$ is the dependent variable, and the explanatory variables are the zonal demand for electricity $\left(\Delta\right.$ Demand $\left._{t, z i}\right)$, zonal electricity production from wind $\left(\Delta\right.$ Wind $\left._{t, z i}\right)$, zonal electricity production from solar $\left(\Delta\right.$ Solar $\left._{t, z i}\right)$, total wind $\left(\sum_{k=1, k \neq i}^{N Z} \Delta\right.$ Wind $\left._{t, z k}\right)$ and solar $\left(\sum_{k=1, k \neq i}^{N Z} \Delta\right.$ Solar $\left._{t, z k}\right)$ generation in other zones $k$, and total electricity demand $\left(\sum_{k=1, k \neq i}^{N Z} \Delta\right.$ Demand $\left._{t, z k}\right)$ on the other zones.

A dummy variable is a numerical variable used in regression analysis to indicate the absence or presence of a group membership. In our models, to control time-specific trends in electricity markets, we considered 23 dummy variables representing the hour of the day ( 1 a.m. to 11 p.m.), 6 dummy variables representing the day of the week (Monday to Saturday), and 11 dummy variables representing the month (January to November). In this regard, $D H_{t}, D D_{t}$, and $D M_{t}$ are the hourly, daily, and monthly dummy variables, respectively.

Then, by using Equation (2), we calculated the influence of increasing wind and solar generation in zone $i$ on the net input flow of the other zones.

$$
\begin{aligned}
& \Delta \operatorname{NetIn}_{t, z k^{\prime}}=\gamma \quad+\delta_{1} \Delta \text { Wind }_{t, z k^{\prime}}+\delta_{2} \Delta \text { Solar }_{t, z k^{\prime}}+\delta_{3} \Delta \text { Demand }_{t, z k^{\prime}}+\delta_{4} \Delta \text { Wind }_{t, z i}+\delta_{5} \Delta \text { Solar }_{t, z i} \\
& +\delta_{6} \sum_{k=1, k \neq i, k \neq k^{\prime}}^{N Z} \Delta \text { Wind }_{t, z k}+\delta_{7} \sum_{k=1, k \neq i, k \neq k^{\prime}}^{N Z} \Delta \text { Solar }_{t, z k}+\delta_{8} \sum_{k=1, k \neq k^{\prime}}^{N Z} \Delta \text { Demand }_{t, z k}+\delta_{9} D H_{t} \\
& +\delta_{10} D D_{t}+\delta_{11} D M_{t}+\varepsilon_{t, z} \\
& \forall k^{\prime} \in k
\end{aligned}
$$


where $k$ is a general index of other zones and $k^{\prime}$ is the index of each member of the other zones.

By implementing Equations (1) and (2), the impact of increasing wind and solar generation on the net input flow of all zones in the Italian electricity market was calculated.

In the next step, using the updated value of net input flow from the previous equations, we calculated the impact of increasing wind and solar generation on each zonal electricity price using daily data.

$$
\begin{gathered}
\Delta \text { Price }_{t, z i}=\alpha+\beta_{1} \Delta \text { Wind }_{t, z i}+\beta_{2} \Delta \text { Solar }_{t, z i}+\beta_{3} \Delta \text { Demand }_{t, z i}+\beta_{4} \Delta \text { NetIn }_{t, z i i^{*}}+\beta_{5} \sum_{k=1, k \neq i}^{N Z} \Delta \operatorname{Net}_{t, z} \operatorname{In}_{t, z k^{*}} \\
+\beta_{6} \Delta \text { NGPrice }_{t}+\beta_{7} D H_{t}+\beta_{8} D D_{t}+\beta_{9} D M_{t}+\varepsilon_{t, z}
\end{gathered}
$$

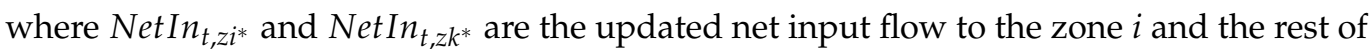
the zones, respectively. NGPrice $t$ denotes the natural gas (NG) price in the Italian electricity market.

The coefficients of interest, $\beta_{1}$ through $\beta_{6}$, represent the average change in the zonal price per additional unit changes in the relevant values, e.g., $\beta_{1}$ represents the average changes in zonal price by increasing a unit in wind generation on the given zone. Due to wind and solar being a zero marginal-cost generation, while all are held constant, additional wind and solar generation suppresses zonal prices. In this regard, the expected sign of the coefficient $\beta_{1}$ and $\beta_{2}$ was negative. We expected coefficient $\beta_{6}$ to have a positive sign, because the wholesale Italian electricity prices closely follow the NG price.

\subsection{Post-Processing}

After fitting the models using OLS and calculating the residuals (residual is the differences between the actual and the fitted observation), we ran tests to check the correctness of our specification, as described in the following subsections.

\subsubsection{Breusch-Pagan Test}

The Breusch-Pagan (BP) test is one of the most common tests for testing the heteroscedasticity of errors in regression [28]. Heteroscedasticity is an unequal scatter or a systematic change in the scatter of the errors over the range of the measured values. The consequence of heteroscedasticity is that the results obtained by the model through significant tests would be inaccurate. In our model, The BP test confirmed the presence of heteroscedasticity.

\subsubsection{Durbin-Watson Test}

We adopted the Durbin-Watson (DW) test to check the presence of autocorrelation between residuals. The result of the DW test verifies if there is autocorrelation between samples.

Consequently, the BP test and DW statistics point to the presence of heteroscedasticity and autocorrelation in the residuals, respectively. In this regard, to obtain heteroscedastic and serially correlated robust standard errors for all the OLS estimates reported, we utilized Newey-West standard errors [29].

\section{Results}

This section first explains the impact of wind and solar production on zonal net input flow, Section 4.1, and then describes the MOE in the zonal market (Section 4.2).

\subsection{Impact of Wind and Solar Generation on the Net Input Flow of Each Zone}

In Table 1, we report the coefficients of Equation (1) for only the zones CNOR and SICI for the sake of brevity. We chose them to represent the north and south zones, respectively. A complete list of the coefficients for the rest of the geographical zones is presented in Appendix A, Tables A7-A12. 
Table 1. OLS estimation of hourly changes in net input flow of CNOR and SICI.

\begin{tabular}{|c|c|c|c|c|c|c|}
\hline Zone & Input Variables & 2015 & 2016 & 2017 & 2018 & 2019 \\
\hline \multirow{9}{*}{$\sum_{0}^{\frac{N}{O}}$} & $\Delta$ Wind & $\begin{array}{c}-0.5394^{* * *} \\
(0.1904)\end{array}$ & $\begin{array}{c}-0.8065^{* * *} \\
(0.1443)\end{array}$ & $\begin{array}{c}-0.8757^{* * *} \\
(0.1361)\end{array}$ & $\begin{array}{c}-0.7107^{* * *} \\
(0.1337)\end{array}$ & $\begin{array}{c}-0.652^{* * *} \\
(0.1368)\end{array}$ \\
\hline & $\Delta$ Solar & $\begin{array}{c}-0.922 * * * \\
(0.0215)\end{array}$ & $\begin{array}{c}-0.7291 * * * \\
(0.0173)\end{array}$ & $\begin{array}{c}-0.8023^{* * *} \\
(0.0211)\end{array}$ & $\begin{array}{c}-0.7821 * * * \\
(0.0189)\end{array}$ & $\begin{array}{c}-0.7772^{* * *} \\
(0.0237)\end{array}$ \\
\hline & $\Delta$ Demand & $\begin{array}{c}0.7426^{* * *} \\
(0.0095)\end{array}$ & $\begin{array}{c}0.7553 * * * \\
(0.0091)\end{array}$ & $\begin{array}{c}0.7527 * * * \\
(0.0119)\end{array}$ & $\begin{array}{l}0.722 * * * \\
(0.0103)\end{array}$ & $\begin{array}{c}0.6984^{* * *} \\
(0.0114)\end{array}$ \\
\hline & $\Delta$ Wind $_{\text {other zones }}$ & $\begin{array}{c}0.0322^{* * *} \\
(0.0049)\end{array}$ & $\begin{array}{c}0.0376^{* * *} \\
(0.005)\end{array}$ & $\begin{array}{c}0.0324^{* * *} \\
(0.0042)\end{array}$ & $\begin{array}{c}0.0339 * * * \\
(0.0038)\end{array}$ & $\begin{array}{c}0.0538^{* * *} \\
(0.0044)\end{array}$ \\
\hline & $\Delta$ Solar $_{\text {other zones }}$ & $\begin{array}{c}0.0297^{* * *} \\
(0.0031)\end{array}$ & $\begin{array}{l}0.0057 * * \\
(0.0025)\end{array}$ & $\begin{array}{c}0.0112^{* * *} \\
(0.003)\end{array}$ & $\begin{array}{c}0.0172^{* * *} \\
(0.0027)\end{array}$ & $\begin{array}{c}0.0314^{* * *} \\
(0.0034)\end{array}$ \\
\hline & $\Delta$ Demand $d_{\text {other zones }}$ & $\begin{array}{c}-0.0083^{* * *} \\
(0.0013)\end{array}$ & $\begin{array}{l}-0.01^{* * *} \\
(0.0012)\end{array}$ & $\begin{array}{l}-0.01^{* * *} \\
(0.0015)\end{array}$ & $\begin{array}{c}-0.0081^{* * *} \\
(0.0014)\end{array}$ & $\begin{array}{c}-0.014^{* * *} \\
(0.0015)\end{array}$ \\
\hline & Dummies & Yes & Yes & Yes & Yes & Yes \\
\hline & Observations & 8760 & 8784 & 8760 & 8760 & 8760 \\
\hline & Adjusted $R^{2}$ & 0.83 & 0.80 & 0.82 & 0.82 & 0.72 \\
\hline \multirow{9}{*}{$\vec{v}$} & $\Delta W i n d$ & $\begin{array}{c}-0.4463^{* * *} \\
(0.0146)\end{array}$ & $\begin{array}{c}-0.5383^{* * *} \\
(0.0183)\end{array}$ & $\begin{array}{c}-0.6949^{* * *} \\
(0.0199)\end{array}$ & $\begin{array}{c}-0.7151^{* * *} \\
(0.0166)\end{array}$ & $\begin{array}{l}-0.74^{* * *} \\
(0.0182)\end{array}$ \\
\hline & $\Delta$ Solar & $\begin{array}{c}-0.2639 * * * \\
(0.0195)\end{array}$ & $\begin{array}{c}-0.2032 * * * \\
(0.0262)\end{array}$ & $\begin{array}{c}-0.3915^{* * *} \\
(0.0303)\end{array}$ & $\begin{array}{c}-0.5646^{* * *} \\
(0.0252)\end{array}$ & $\begin{array}{c}-0.5576^{* * *} \\
(0.029)\end{array}$ \\
\hline & $\Delta$ Demand & $\begin{array}{c}0.0941^{* * *} \\
(0.0103)\end{array}$ & $\begin{array}{c}0.111^{* * *} \\
(0.013)\end{array}$ & $\begin{array}{c}0.2949^{* * *} \\
(0.0163)\end{array}$ & $\begin{array}{l}0.377^{* * *} \\
(0.0145)\end{array}$ & $\begin{array}{c}0.3923^{* * *} \\
(0.0167)\end{array}$ \\
\hline & $\Delta W_{i n d}$ other zones & $\begin{array}{c}0.0268^{* * *} \\
(0.0045)\end{array}$ & $\begin{array}{c}0.0364^{* * *} \\
(0.006)\end{array}$ & $\begin{array}{c}0.049^{* * *} \\
(0.006)\end{array}$ & $\begin{array}{l}0.0585^{* * *} \\
(0.0054)\end{array}$ & $\begin{array}{l}0.0313^{* * *} \\
(0.0051)\end{array}$ \\
\hline & $\Delta$ Solar $_{\text {other zones }}$ & $\begin{array}{c}0.0083^{* * *} \\
(0.0018)\end{array}$ & $\begin{array}{c}0.0004 \\
(0.0024)\end{array}$ & $\begin{array}{c}0.0126^{* * *} \\
(0.0027)\end{array}$ & $\begin{array}{c}0.0167^{* * *} \\
(0.0023)\end{array}$ & $\begin{array}{c}0.0169 * * * \\
(0.0026)\end{array}$ \\
\hline & $\Delta$ Demand $_{\text {other zones }}$ & $\begin{array}{c}-0.0082 * * * \\
(0.0007)\end{array}$ & $\begin{array}{c}-0.0052 * * * \\
(0.0009)\end{array}$ & $\begin{array}{c}-0.0118^{* * *} \\
(0.0011)\end{array}$ & $\begin{array}{c}-0.0109 * * * \\
(0.001)\end{array}$ & $\begin{array}{c}-0.0096^{* * *} \\
(0.0011)\end{array}$ \\
\hline & Dummies & Yes & Yes & Yes & Yes & Yes \\
\hline & Observations & 8760 & 8784 & 8760 & 8760 & 8760 \\
\hline & Adjusted $R^{2}$ & 0.14 & 0.13 & 0.19 & 0.30 & 0.28 \\
\hline
\end{tabular}

Note: All the models include an intercept; standard errors in parenthesis are robust to heteroscedasticity and serial correlation. ${ }^{* * *}$ indicates $p$-value $<0.001,{ }^{* *} p$-value $<0.01,{ }^{*} p$-value $<0.05, p$-value $<0.1$.

The interpretation of coefficients reported in Table 1 for wind and solar generation is straightforward; for instance, for every additional MWh of wind generation in CNOR in 2017, net input flow in the same zone, CNOR, would be decreased by $0.8757 \mathrm{MWh}$. In 2017 , this model explained $82 \%$ of the hourly net input flow to CNOR (Adjusted $R^{2}$ ). In this model, based on the $p$-value, all coefficients of wind and solar were significant.

We can have similar interpretations for other explanatory variables, e.g., solar, load, etc.

Figures 6 and 7 report the estimated coefficients of Equations (1) and (2) to have better visualization. They show the impact of a $100 \mathrm{MWh}$ increment in the wind and solar generation in CNOR and SICI on the net input flow in all zones from 2015 to 2019 separately. In this way, cross-effects among the zones can be evaluated. 
CNOR

\begin{tabular}{|c|c|c|c|c|c|}
\hline CNOR & -53.9 & -80.7 & -87.6 & -71.1 & -65.2 \\
\hline CSUD & 0 & 0 & 0 & 0 & 0 \\
\hline NORD & 0 & 0 & 0 & 0 & 0 \\
\hline SARD & 0 & 0 & 0 & 0 & 0 \\
\hline $\mathrm{SICl}$ & 36.6 & 0 & 0 & 0 & 0 \\
\hline SUD & 0 & 0 & 0 & 76.7 & 0 \\
\hline
\end{tabular}

$\mathrm{SICl}$

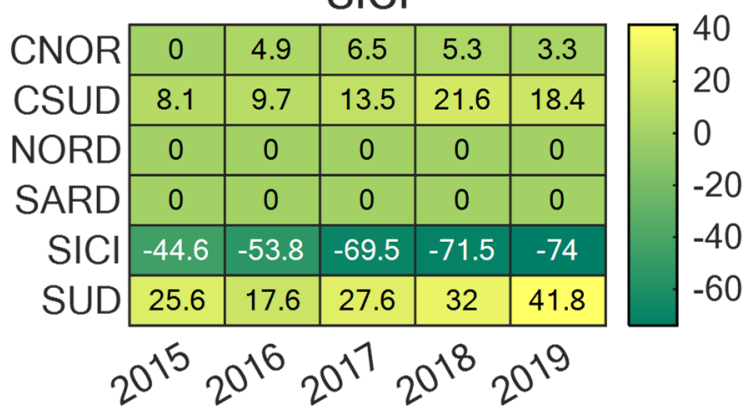

Figure 6. Heatmap chart of the impact of $100 \mathrm{MW}$ increases in wind generation in CNOR and SICI on the net input flow (MW); results of Equations (1) and (2).

CNOR

\begin{tabular}{|c|c|c|c|c|c|c|}
\hline CNOR & -92.2 & -72.9 & -80.2 & -78.2 & -77 & 40 \\
\hline CSUD & 0 & 0 & 0 & 0 & 0 & \\
\hline NORD & 26.5 & 0 & 45 & 27.7 & 32.3 & \\
\hline SARD & 0 & 1.5 & 0 & 0 & 0 & -4 \\
\hline $\mathrm{SICl}$ & 0 & 0 & 4.9 & 6.2 & 4.7 & -6 \\
\hline SUD & 0 & 0 & 0 & 0 & 0 & -8 \\
\hline
\end{tabular}

$\mathrm{SICl}$

\begin{tabular}{|c|c|c|c|c|c|}
\hline $\mathrm{CNOR}$ & 13.8 & 0 & 0 & 8.4 & 0 \\
\hline CSUD & 20.2 & 25.9 & 19.8 & 0 & 31.1 \\
\hline NORD & 0 & 0 & 31.3 & 46.9 & 24.2 \\
\hline SARD & 0 & -2.6 & 0 & -3 & -3.6 \\
\hline $\mathrm{SICl}$ & -26.4 & -20.3 & -39.1 & -56.5 & -55.8 \\
\hline SUD & 27.8 & 0 & 15.4 & 10.6 & 0 \\
\hline
\end{tabular}

Figure 7. Heatmap chart of the impact of $100 \mathrm{MWh}$ increases in solar generation in CNOR and SICI on the net input flow (MW); results of Equations (1) and (2).

Based on the figures, on the one hand, by increasing $100 \mathrm{MWh}$ of wind production in SICI in 2018, the net input flow of SICI would be decreased by $71.5 \mathrm{MWh}$. The results are the outcome of Equation (1). On the other hand, by increasing $100 \mathrm{MWh}$ of wind production in SICI in 2018, the net input flow of SUD, CSUD, and CNOR would increase by $32 \mathrm{MWh}$, 21.6 MWh, and 5.3 MWh, respectively. The results are the outcome of Equation (2).

A similar explanation applies to the reported results for solar generation (Figure 7).

The complete results for the other geographical zones are presented in Appendix A, Figures A1 and A2.

It is worth mentioning that the coefficients that were not significant ( $p$-value $\geq 0.1$ ) were set as zero.

\subsection{Impact of Wind and Solar Generation on the Zonal Market Price}

Table 2 lists the results of Equation (3) run over five different years, namely 2015 to 2019. The coefficients show the impacts of a $1 \mathrm{MW}$ increment in the daily wind and solar generation on the zonal price. For instance, in SICI in 2019, the impact of a $100 \mathrm{MW}$ increase in wind and solar generation would lead to a price reduction of $4.97 € / \mathrm{MWh}$ and 3.6€/MWh, respectively. This result is an indication of the MOE in the Italian zonal price market. 
Table 2. OLS estimation of daily changes in electricity prices of CNOR; results of Equation (3).

\begin{tabular}{|c|c|c|c|c|c|c|}
\hline Zone & Input Variables & 2015 & 2016 & 2017 & 2018 & 2019 \\
\hline \multirow{9}{*}{ 艺 } & $\Delta$ Wind & $\begin{array}{c}-0.1081^{* * *} \\
(0.0205)\end{array}$ & $\begin{array}{c}-0.0421^{* * *} \\
(0.0135)\end{array}$ & $\begin{array}{c}-0.0494^{* * *} \\
(0.018)\end{array}$ & $\begin{array}{c}-0.0552^{* * *} \\
(0.0143)\end{array}$ & $\begin{array}{c}-0.0523^{* * *} \\
(0.0103)\end{array}$ \\
\hline & $\Delta$ Solar & $\begin{array}{c}-0.0134^{* * *} \\
(0.0048)\end{array}$ & $\begin{array}{c}-0.0104^{* * *} \\
(0.0037)\end{array}$ & $\begin{array}{c}-0.0115^{* *} \\
(0.0052)\end{array}$ & $\begin{array}{c}-0.0141^{* * *} \\
(0.0036)\end{array}$ & $\begin{array}{c}-0.0073^{* *} \\
(0.0033)\end{array}$ \\
\hline & $\Delta$ Demand & $\begin{array}{c}0.0154^{* * *} \\
(0.0022)\end{array}$ & $\begin{array}{l}0.0124^{* * *} \\
(0.0014)\end{array}$ & $\begin{array}{c}0.0148^{* * *} \\
(0.002)\end{array}$ & $\begin{array}{l}0.012 * * * \\
(0.0012)\end{array}$ & $\begin{array}{l}0.008^{* * *} \\
(0.0009)\end{array}$ \\
\hline & $\Delta$ NetIn & $\begin{array}{c}-0.0066^{* *} \\
(0.0028)\end{array}$ & $\begin{array}{c}-0.007^{* * *} \\
(0.0019)\end{array}$ & $\begin{array}{c}-0.0068^{* * *} \\
(0.0023)\end{array}$ & $\begin{array}{c}-0.0064^{* * *} \\
(0.0016)\end{array}$ & $\begin{array}{c}0.0013 \\
(0.0013)\end{array}$ \\
\hline & $\Delta$ NetIn ${ }_{\text {other }}$ & $\begin{array}{l}-0.0008 * * \\
(0.0003)\end{array}$ & $\begin{array}{c}-0.0007^{* * *} \\
(0.0002)\end{array}$ & $\begin{array}{l}-0.0001 \\
(0.0003)\end{array}$ & $\begin{array}{l}-0.0002 \\
(0.0002)\end{array}$ & $\begin{array}{l}-0.0001 \\
(0.0003)\end{array}$ \\
\hline & $\triangle N G$ Price & $\begin{array}{c}0.3156 \\
(0.6552)\end{array}$ & $\begin{array}{l}0.4129 * * \\
(0.1924)\end{array}$ & $\begin{array}{c}1.1197^{* * *} \\
(0.2007)\end{array}$ & $\begin{array}{l}1.3786^{* * *} \\
(0.1415)\end{array}$ & $\begin{array}{l}0.6375^{*} \\
(0.3332)\end{array}$ \\
\hline & Dummies & Yes & Yes & Yes & Yes & Yes \\
\hline & Observations & 365 & 366 & 365 & 365 & 365 \\
\hline & Adjusted $R^{2}$ & 0.40 & 0.38 & 0.44 & 0.51 & 0.43 \\
\hline \multirow{9}{*}{$\vec{v}$} & $\Delta W i n d$ & $\begin{array}{c}-0.0206^{* * *} \\
(0.0018)\end{array}$ & $\begin{array}{c}-0.0196^{* * *} \\
(0.0011)\end{array}$ & $\begin{array}{c}-0.0293^{* * *} \\
(0.0016)\end{array}$ & $\begin{array}{c}-0.0357^{* * *} \\
(0.002)\end{array}$ & $\begin{array}{c}-0.0497^{* * *} \\
(0.0025)\end{array}$ \\
\hline & $\Delta$ Solar & $\begin{array}{c}-0.0242 * * * \\
(0.0082)\end{array}$ & $\begin{array}{c}-0.0223 * * * \\
(0.0057)\end{array}$ & $\begin{array}{c}-0.0163 * \\
(0.009)\end{array}$ & $\begin{array}{c}-0.0239^{* * *} \\
(0.0088)\end{array}$ & $\begin{array}{c}-0.036^{* * *} \\
(0.0105)\end{array}$ \\
\hline & $\Delta$ Demand & $\begin{array}{l}0.0079 * * \\
(0.0033)\end{array}$ & $\begin{array}{c}0.0162 * * * \\
(0.0021)\end{array}$ & $\begin{array}{l}0.034^{* * *} \\
(0.0031)\end{array}$ & $\begin{array}{c}0.0353^{* * *} \\
(0.0038)\end{array}$ & $\begin{array}{c}0.0567^{* * *} \\
(0.0041)\end{array}$ \\
\hline & $\Delta$ NetIn & $\begin{array}{c}0.0021 \\
(0.0051)\end{array}$ & $\begin{array}{c}-0.018^{* * *} \\
(0.0019)\end{array}$ & $\begin{array}{c}-0.0228 * * * \\
(0.0024)\end{array}$ & $\begin{array}{c}-0.0271 * * * \\
(0.003)\end{array}$ & $\begin{array}{c}-0.037 * * * \\
(0.0036)\end{array}$ \\
\hline & $\Delta$ NetIn $_{\text {other }}$ & $\begin{array}{l}0.0007^{* *} \\
(0.0003)\end{array}$ & $\begin{array}{l}-0.0003 \\
(0.0002)\end{array}$ & $\begin{array}{l}-0.0001 \\
(0.0003)\end{array}$ & $\begin{array}{l}0.001^{* * *} \\
(0.0004)\end{array}$ & $\begin{array}{c}0.0002 \\
(0.0005)\end{array}$ \\
\hline & $\triangle N G$ Price & $\begin{array}{c}1.0011 \\
(0.6794)\end{array}$ & $\begin{array}{c}-0.4207 * * \\
(0.19)\end{array}$ & $\begin{array}{c}0.6942 * * * \\
(0.2041)\end{array}$ & $\begin{array}{c}0.9578^{* * *} \\
(0.2161)\end{array}$ & $\begin{array}{c}-0.28 \\
(0.6208)\end{array}$ \\
\hline & Dummies & Yes & Yes & Yes & Yes & Yes \\
\hline & Observations & 365 & 366 & 365 & 365 & 365 \\
\hline & Adjusted $R^{2}$ & 0.41 & 0.42 & 0.57 & 0.56 & 0.63 \\
\hline
\end{tabular}

All the models include an intercept; standard errors in parenthesis are robust to heteroscedasticity and serial correlation. ${ }^{* * *}$ indicates $p$-value $<0.001,{ }^{* *} p$-value $<0.01,{ }^{*} p$-value $<0.05, p$-value $<0.1$.

All explanatory variables were statistically significant for wind and solar. In line with the definition of MOE, the coefficients of wind and solar were negative in all specifications. Moreover, as expected, the coefficients related to the load were always positive. For a greater load, more generators should be dispatched, and the market-clearing price will be higher. Moreover, the coefficient estimates of NG price were generally positive. In this model, by considering these explanatory variables, explanatory power varied between $38 \%$ and $51 \%$ for CNOR and between $41 \%$ and $63 \%$ for SICI.

The results of Equation (3) run over other geographical zones are presented in Appendix A, Tables A13-A18.

Figure 8 displays how much the $100 \mathrm{MW}$ increase in wind generation in each region would affect the electricity price in a given zone between 2015 and 2019. The color for the lowest value is bright green, and for the greatest value, it is dark green. Based on the figure, in SICI, the green color gets darker as the year increases. For instance, in 2018, increasing wind generation in CNOR had more impact on the zonal price than other zones. We can have a similar interpretation for the map charts in Figure 9. 

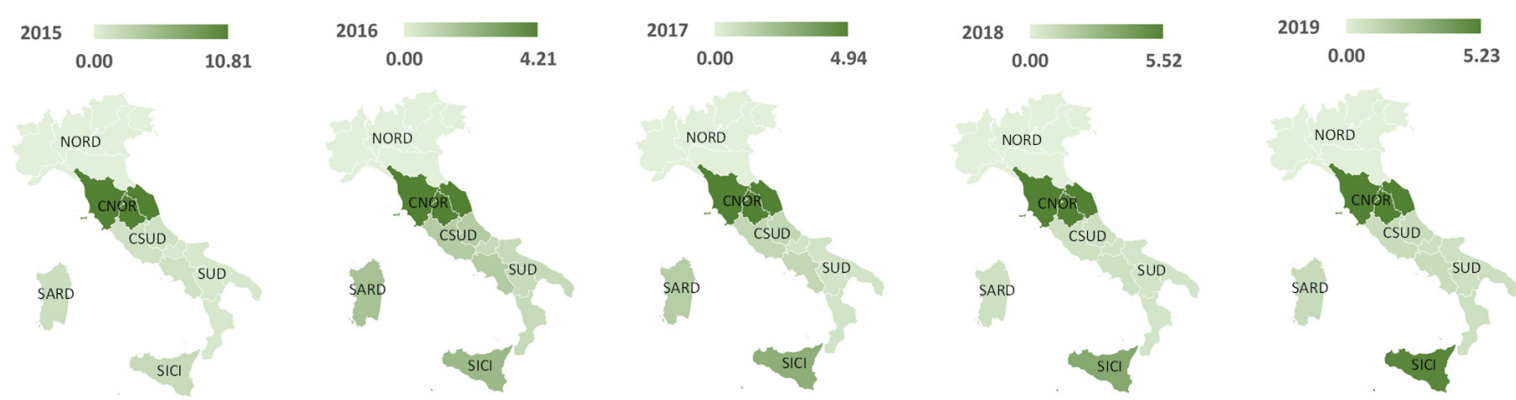

Figure 8. A $100 \mathrm{MW}$ increase in wind generation in each zone; impact on electricity price in the same zone (€/MWh); 2015-2019.
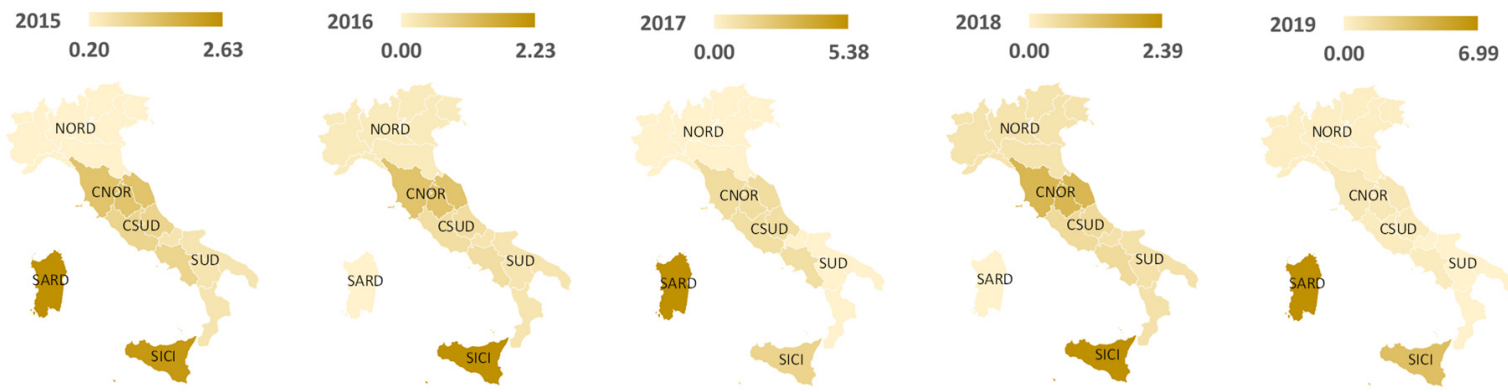

Figure 9. A $100 \mathrm{MW}$ increase in solar generation in each zone; impact on electricity price in the same zone (€/MWh); 2015-2019.

Figure 10 provides a graphical representation of the wind and solar coefficients. The impact level of wind and solar energy may vary between different zones from year to year based on the energy mix and different penetration. In CNOR, an increment of solar production had a more considerable impact than wind for all the considered years. In SICI, in 2015 and 2016, the effect of solar was slightly more significant in absolute value than wind generation, which was different from what occurred in the next three years.
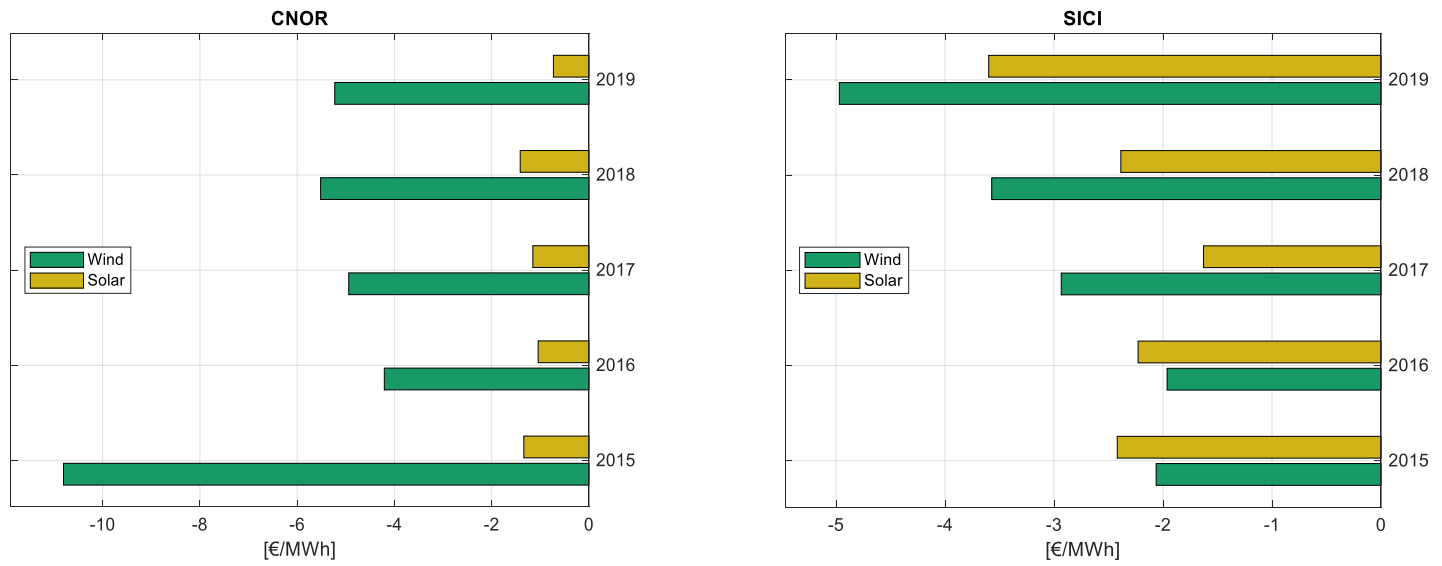

Figure 10. Impact of $100 \mathrm{MW}$ increases in wind and solar generation on the zonal electricity price in CNOR and SICI; 2015 to 2019.

An increase in wind and solar generation will shift the short-term market supply curve to the right. This phenomenon results in a decrease in electricity prices. The MOE results from wind and solar will depend on supply and demand and will probably vary from year to year. In this regard, we considered the estimated coefficients of the most recent year, 2019 , to explain the model results. Figure 11 summarizes the impact of $100 \mathrm{MW}$ increment of wind and solar generation on the zonal electricity price in 2019, considering each zone separately. The $100 \mathrm{MW}$ increment of wind production resulted in a price reduction within 
the range of 5.23€/MWh in CNOR and 0.77€/MWh in SUD. Considering solar generation, similar decrements could be noticed: it ranged from 6.99€/MWh in SARD to $0.26 € / \mathrm{MWh}$ in NORD. As mentioned before, the coefficients that were not significant ( $p$-value $\geq 0.1$ ) are presented by zero (NORD in the wind).

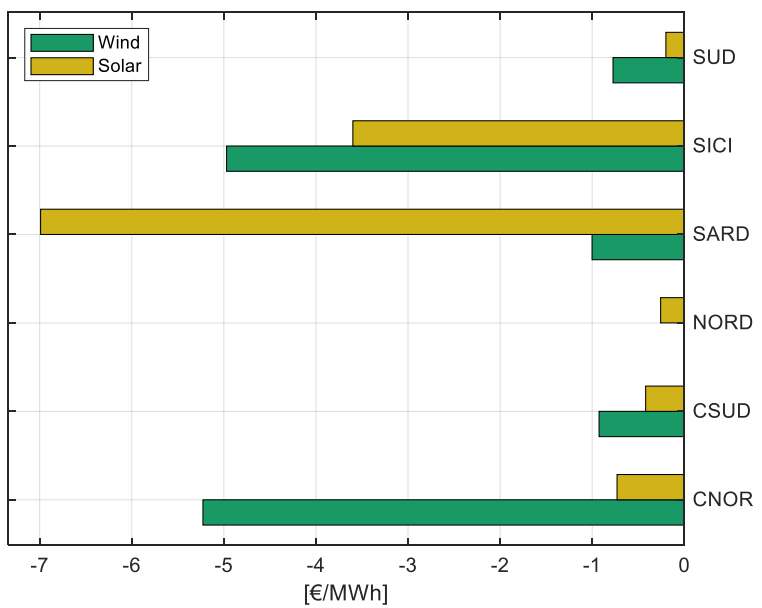

Figure 11. Comparison of the impact of $100 \mathrm{MW}$ increases in wind and solar generation on electricity price in different zones in 2019.

Moreover, Table 3 lists the impact of wind and solar increment on the zonal prices as a percent of the average zonal electricity price in each zone in 2019.

Table 3. Impact of $100 \mathrm{MW}$ increases in wind and solar generation on different zonal price; percent of average zonal price in 2019.

\begin{tabular}{ccc}
\hline & \multicolumn{3}{c}{ Impact on Zonal Price } \\
\hline Zone & Wind & Solar \\
\hline CNOR & $-10 \%$ & $-1.4 \%$ \\
\hline CSUD & $-1.77 \%$ & $-0.8 \%$ \\
\hline NORD & $0 \%$ & $-0.5 \%$ \\
\hline SARD & $-1.93 \%$ & $-13.5 \%$ \\
\hline SICI & $-7.92 \%$ & $-5.7 \%$ \\
\hline SUD & $-1.52 \%$ & $-0.39 \%$ \\
\hline
\end{tabular}

Based on Figure 11 and Table 3, the wind seemed to be the main driver of the MOE in all the geographical zones in 2019, except for SARD. In SARD, the impact of solar generation was much higher than wind generation in the given year. Expanding wind generation in zones CNOR and SICI should produce the most benefits in terms of PUN reduction. Figure 11 also shows a pronounced decrement in prices of SARD and SICI due to the increment of solar generation. Thus, PUN can be reduced by solar generation expansion as well. However, we should point out that these coefficients are deeply dependent on wind and solar penetration, total cross-zonal exchanges, and total demand in each zone.

The adjusted $\mathrm{R}^{2}$ values for the 2019 zonal market price regressions are reported in the result tables (Tables A7-A18) for all the zones. These regressions had a perfect fit, except for the net input flow of CSUD and NORD, due to the large size of the dataset and the extreme volatility of the zonal price [30]. The key finding from the zonal market analysis is that the impact of wind and solar differed over zones, showing that different zonal markets can integrate high penetration of wind and solar generation. Considering wind generation, in CNOR, for instance, although the wind generation is relatively lower than other zones, the merit order effect is comparatively high. In SUD, on the other hand, MOE is not as substantial, and the penetration for wind and solar power is also quite high. The main 
reason is that SUD is an exporter zone, so this zone allocates large shares of wind and solar production to export to neighboring regions if necessary.

\section{Conclusions}

The growing integration of intermittent RES technologies, wind and solar, and the national support schemes being applied by different countries has led to understanding the impact of the sources on the electricity market.

In this paper, we used econometric approaches for the Italian zonal electricity market, which is one of the unique electricity markets in Europe with a significant amount of wind and solar generation in different zones, to investigate the Merit Order Effect (MOE) in each zone by looking at market data from January 2015 to December 2019. Firstly, the impact of increasing wind and solar electricity generation on the net input flow in each zone was quantified by using hourly data to measure the MOE. In the next step, using the estimated coefficients of the previous step, the MOE of the wind and solar production in each zone was measured.

Studying the real historical data, by increasing $100 \mathrm{MWh}$ of wind and solar production in CNOR, the net input flow of CNOR would have decreased ranges from 53.9 to $87.6 \mathrm{MWh}$, and from 72.9 to 92.2 , respectively. On the other hand, increasing wind and solar in SICI not only decreases the zone's input flow but also widely changes other zones' exchange statuses.

Moreover, the price-damping effect of wind and solar infeed, MOE, was confirmed in each zonal market.

However, the intensity of the price depression differs between each zone, which displays that some zones are more capable of integrating wind and solar generation than others. It is mainly because of the RES penetration, cross-zonal exchanges, zonal demand, and storage capacity of each zone.

Results from the multivariate regression model looking at the impact of an additional $100 \mathrm{MW}$ of wind infeed on zonal prices show average decreases, over five years, of around 6.14, 0.99, 1.01, 3.1, and 0.64€/MWh for CNOR, CSUD, SARD, SICI, and SUD, respectively. The outcomes for an additional $100 \mathrm{MW}$ of solar infeed decreases, over five years, by around $1.13,0.68,0.19,3.0,2.45$, and $0.28 € /$ MWh for CNOR, CSUD, NORD, SARD, SICI, and SUD, respectively. The regions with the higher absolute value of MOE will become more appealing investment choices for national support schemes and RES developers.

The policy implications inspired by the current study can be summarized as follows. The study results could provide investors and decision-makers with helpful information to locate new wind farms and solar panels to maximize their profits. The electricity price reduction for end-users due to the MOE depends on the RES penetration level, market concentration, and competitiveness. The wind and PV generation increment has two opposite effects in the definition of the electric energy cost: on the one hand, it reduces the wholesale electricity price when wind and sun are available in the day-ahead markets; on the other hand, it can lead to an increase in the costs related to security and reliability of the network in the ancillary service markets. Considering the environmental goals of the European Union, the RES penetration level will quickly increase in the next years. Market mechanisms to drive the energetic transition should be designed to maximize social welfare, incentivizing the installations of new RES power plants in the market zones with the highest positive impacts. Therefore, the research outcomes could be helpful to organize an efficient zonal market structure and pave the way for high wind and solar penetration by making operative and sustainable renewable policies.

The lessons learned here are beneficial and applicable for wholesale electricity markets in other EU and non-EU countries with similar market structures and data availability, e.g., Nord Pool, Ontario, and Midcontinent Independent System Operator (MISO) electricity markets. 
Several pathways for future studies can be explored, such as evaluating the RES impacts on congestion among market zones and on the electrical energy price, considering both the wholesale energy price reduction and the extra ancillary service costs.

Author Contributions: All authors contributed to conceptualization, methodology, validation, formal analysis, investigation, writing, and supervision. All authors have read and agreed to the published version of the manuscript.

Funding: This research received no external funding.

Conflicts of Interest: The authors declare no conflict of interest.

\section{Appendix A}

Table A1. Augmented Dickey-Fuller test statistics in 1st difference; CNOR.

\begin{tabular}{|c|c|c|c|c|c|c|}
\hline \multirow{8}{*}{ 艿 } & Input Variables & 2015 & 2016 & 2017 & 2018 & 2019 \\
\hline & $\Delta$ Wind & -11.54 & -11.84 & -10.31 & -10.67 & -10.93 \\
\hline & $\Delta$ Solar & -11.48 & -10.25 & -10.82 & -8.73 & -12 \\
\hline & $\Delta$ Demand & -7.73 & -7.84 & -6.78 & -7.43 & -8.04 \\
\hline & $\Delta$ NetIn & -7.95 & -9.41 & -8.16 & -8.75 & -7.97 \\
\hline & $\Delta$ NetIn $_{\text {other zones }}$ & -7.64 & -7.94 & -8.25 & -8.93 & -8.06 \\
\hline & $\triangle N G P r i c e$ & -7.97 & -4.49 & -8.04 & -8.34 & -6.52 \\
\hline & $\triangle$ ZonalPrice & -9.45 & -8.73 & -7.51 & -7.08 & -8.1 \\
\hline
\end{tabular}

Table A2. Augmented Dickey-Fuller test statistics in 1st difference; CSUD.

\begin{tabular}{ccccccc}
\hline & Input Variables & $\mathbf{2 0 1 5}$ & $\mathbf{2 0 1 6}$ & $\mathbf{2 0 1 7}$ & $\mathbf{2 0 1 8}$ & $\mathbf{2 0 1 9}$ \\
\cline { 2 - 7 } & $\Delta$ Wind & -11.11 & -11.21 & -10.52 & -10.91 & -12.23 \\
\cline { 2 - 6 } & $\Delta$ Solar & -11.76 & -10.03 & -10.98 & -8.69 & -11.74 \\
\cline { 2 - 6 } & $\Delta$ Demand & -6.89 & -7.12 & -7.09 & -6.93 & -8.25 \\
\cline { 2 - 7 } & $\Delta$ NetIn & -8.5 & -9.85 & -8.77 & -9 & -8.39 \\
\cline { 2 - 6 } & -7.44 & -7.75 & -8.5 & -8.79 & -8.05 \\
\cline { 2 - 6 } & $\Delta$ NetIn $n_{\text {other zones }}$ & -7.97 & -4.49 & -8.04 & -8.34 & -6.52 \\
\hline$\Delta$ NGPrice & -9.63 & -9.26 & -8.91 & -7.45 & -8.76 \\
\hline
\end{tabular}

Table A3. Augmented Dickey-Fuller test statistics in 1st difference; NORD.

\begin{tabular}{|c|c|c|c|c|c|c|}
\hline \multirow{8}{*}{$\begin{array}{l}\stackrel{0}{0} \\
\stackrel{0}{0} \\
Z\end{array}$} & Input Variables & 2015 & 2016 & 2017 & 2018 & 2019 \\
\hline & $\Delta W i n d$ & -9.87 & -10.36 & -9.49 & -9.98 & -11.51 \\
\hline & $\Delta$ Solar & -11.15 & -11.49 & -11.57 & -9.48 & -12.37 \\
\hline & $\Delta$ Demand & -7.72 & -7.27 & -6.56 & -7.3 & -7.44 \\
\hline & $\Delta$ NetIn & -7.77 & -7.5 & -8.26 & -8.84 & -7.91 \\
\hline & $\Delta$ NetIn ${ }_{\text {other zones }}$ & -8.4 & -9.05 & -9.22 & -8.93 & -9.82 \\
\hline & $\triangle N G$ Price & -7.97 & -4.49 & -8.04 & -8.34 & -6.52 \\
\hline & $\Delta$ ZonalPrice & -8.37 & -8.39 & -7.26 & -7.25 & -7.83 \\
\hline
\end{tabular}


Table A4. Augmented Dickey-Fuller test statistics in 1st difference; SARD.

\begin{tabular}{|c|c|c|c|c|c|c|}
\hline \multirow{8}{*}{ 幽 } & Input Variables & 2015 & 2016 & 2017 & 2018 & 2019 \\
\hline & $\Delta$ Wind & -9.47 & -9.17 & -10.57 & -10.64 & -10.59 \\
\hline & $\Delta$ Solar & -10.52 & -9.67 & -10.88 & -8.88 & -11.77 \\
\hline & $\Delta$ Demand & -6.94 & -8.23 & -7.82 & -9.77 & -10.19 \\
\hline & $\Delta$ NetIn & -9.12 & -9.79 & -10.43 & -9.48 & -9.58 \\
\hline & $\Delta$ NetIn other zones & -7.37 & -7.58 & -8.2 & -8.89 & -7.94 \\
\hline & $\triangle$ NGPrice & -7.97 & -4.49 & -8.04 & -8.34 & -6.52 \\
\hline & $\Delta$ ZonalPrice & -9.52 & -9.34 & -9.04 & -7.66 & -9.08 \\
\hline
\end{tabular}

Table A5. Augmented Dickey-Fuller test statistics in 1st difference; SICI.

\begin{tabular}{|c|c|c|c|c|c|c|}
\hline \multirow{8}{*}{$\vec{v}$} & Input Variables & 2015 & 2016 & 2017 & 2018 & 2019 \\
\hline & $\Delta$ Wind & -10.27 & -10.57 & -10.3 & -10.35 & -11.1 \\
\hline & $\Delta$ Solar & -10.91 & -9.91 & -9.19 & -9.76 & -9.96 \\
\hline & $\Delta$ Demand & -6.88 & -8.14 & -7.33 & -7.56 & -7.48 \\
\hline & $\Delta$ NetIn & -9.14 & -9.17 & -8.67 & -8.59 & -8.95 \\
\hline & $\Delta$ NetIn $n_{\text {other zones }}$ & -7.39 & -7.56 & -8.07 & -8.97 & -7.85 \\
\hline & $\Delta$ NGPrice & -7.97 & -4.49 & -8.04 & -8.34 & -6.52 \\
\hline & $\Delta$ ZonalPrice & -11.3 & -9.9 & -9.26 & -9.17 & -9.4 \\
\hline
\end{tabular}

Table A6. Augmented Dickey-Fuller test statistics in 1st difference; SUD.

\begin{tabular}{|c|c|c|c|c|c|c|}
\hline \multirow{8}{*}{$\rho_{\omega}$} & Input Variables & 2015 & 2016 & 2017 & 2018 & 2019 \\
\hline & $\Delta$ Wind & -11.08 & -11.65 & -10.88 & -10.65 & -11.61 \\
\hline & $\Delta$ Solar & -10.16 & -10.38 & -11.02 & -9.12 & -11.22 \\
\hline & $\Delta$ Demand & -7.18 & -8.62 & -7.67 & -7.4 & -7.56 \\
\hline & $\Delta$ NetIn & -9.06 & -10.51 & -10.01 & -9.45 & -9.63 \\
\hline & $\Delta$ NetIn other zones & -7.41 & -7.48 & -8.02 & -8.78 & -8.25 \\
\hline & $\triangle$ NGPrice & -7.97 & -4.49 & -8.04 & -8.34 & -6.52 \\
\hline & $\triangle$ ZonalPrice & -10.33 & -9.41 & -9.04 & -7.91 & -9.8 \\
\hline
\end{tabular}

Notes: Critical values for rejection of hypothesis of a unit root are -2.57 (for $10 \%$ confidence level), -2.86 (for $5 \%$ confidence level), and -3.43 (for 1\% confidence level) for the models with drift only; -3.12 (for $10 \%$ confidence level), -3.41 (for $5 \%$ confidence level), -3.96 (for 1\% confidence level) for models that include also the trend [31] We include a trend in the specification of the model.

Table A7. OLS estimation of hourly changes in net input flow of CNOR; results of Equation (1).

\begin{tabular}{|c|c|c|c|c|c|}
\hline CNOR & 2015 & 2016 & 2017 & 2018 & 2019 \\
\hline$\Delta W i n d$ & $\begin{array}{c}-0.5394^{* * *} \\
(0.1904)\end{array}$ & $\begin{array}{c}-0.8065^{* * *} \\
(0.1443)\end{array}$ & $\begin{array}{c}-0.8757^{* * *} \\
(0.1361)\end{array}$ & $\begin{array}{c}-0.7107^{* * *} \\
(0.1337)\end{array}$ & $\begin{array}{c}-0.652^{* * *} \\
(0.1368)\end{array}$ \\
\hline$\Delta$ Solar & $\begin{array}{c}-0.922 * * * \\
(0.0215)\end{array}$ & $\begin{array}{c}-0.7291 * * * \\
(0.0173)\end{array}$ & $\begin{array}{c}-0.8023^{* * *} \\
(0.0211)\end{array}$ & $\begin{array}{c}-0.7821^{* * *} \\
(0.0189)\end{array}$ & $\begin{array}{c}-0.7772 \text { *** } \\
(0.0237)\end{array}$ \\
\hline$\Delta$ Demand & $\begin{array}{c}0.7426^{* * * *} \\
(0.0095)\end{array}$ & $\begin{array}{c}0.7553 * * * \\
(0.0091)\end{array}$ & $\begin{array}{c}0.7527^{* * *} \\
(0.0119)\end{array}$ & $\begin{array}{l}0.722 * * * \\
(0.0103)\end{array}$ & $\begin{array}{c}0.6984^{* * *} \\
(0.0114)\end{array}$ \\
\hline$\Delta$ Wind $_{\text {other zones }}$ & $\begin{array}{c}0.0322 * * * \\
(0.0049)\end{array}$ & $\begin{array}{c}0.0376^{* * *} \\
(0.005)\end{array}$ & $\begin{array}{c}0.0324 * * * \\
(0.0042)\end{array}$ & $\begin{array}{c}0.0339 * * * \\
(0.0038)\end{array}$ & $\begin{array}{c}0.0538^{* * *} \\
(0.0044)\end{array}$ \\
\hline$\Delta$ Solar $_{\text {other zones }}$ & $\begin{array}{c}0.0297 * * * \\
(0.0031)\end{array}$ & $\begin{array}{c}0.0057 * * \\
(0.0025)\end{array}$ & $\begin{array}{c}0.0112 * * * \\
(0.003)\end{array}$ & $\begin{array}{c}0.0172 * * * \\
(0.0027)\end{array}$ & $\begin{array}{c}0.0314 * * * \\
(0.0034)\end{array}$ \\
\hline$\Delta$ Demand $_{\text {other zones }}$ & $\begin{array}{c}-0.0083^{* * *} \\
(0.0013)\end{array}$ & $\begin{array}{c}-0.01 * * * \\
(0.0012)\end{array}$ & $\begin{array}{l}-0.01 * * * \\
(0.0015)\end{array}$ & $\begin{array}{c}-0.0081^{* * *} \\
(0.0014)\end{array}$ & $\begin{array}{c}-0.014^{* * *} \\
(0.0015)\end{array}$ \\
\hline Dummies & Yes & Yes & Yes & Yes & Yes \\
\hline Observations & 8760 & 8784 & 8760 & 8760 & 8760 \\
\hline Adjusted $R^{2}$ & 0.83 & 0.80 & 0.82 & 0.82 & 0.72 \\
\hline
\end{tabular}

All the models include an intercept; standard errors in parenthesis are robust to heteroscedasticity and serial correlation. ${ }^{* * *}$ indicates $p$-value $<0.001,{ }^{* *} p$-value $<0.01,{ }^{*} p$-value $<0.05, p$-value $<0.1$. 
Table A8. OLS estimation of hourly changes in net input flow of CSUD; results of Equation (1).

\begin{tabular}{|c|c|c|c|c|c|}
\hline CSUD & 2015 & 2016 & 2017 & 2018 & 2019 \\
\hline$\Delta$ Wind & $\begin{array}{c}-0.7392 * * * \\
(0.0467)\end{array}$ & $\begin{array}{c}-0.6666^{* * *} \\
(0.0461)\end{array}$ & $\begin{array}{c}-0.7051^{* * *} \\
(0.0492)\end{array}$ & $\begin{array}{c}-0.8523^{* * *} \\
(0.0449)\end{array}$ & $\begin{array}{c}-0.8439^{* * *} \\
(0.0394)\end{array}$ \\
\hline$\Delta$ Solar & $\begin{array}{c}-0.7165^{* * *} \\
(0.0363)\end{array}$ & $\begin{array}{c}-0.3944^{* * *} \\
(0.0395)\end{array}$ & $\begin{array}{c}-0.5554 * * * \\
(0.0401)\end{array}$ & $\begin{array}{c}-0.6527^{* * *} \\
(0.0341)\end{array}$ & $\begin{array}{c}-0.6153^{* * *} \\
(0.0342)\end{array}$ \\
\hline$\Delta$ Demand & $\begin{array}{c}0.5216^{* * *} \\
(0.013)\end{array}$ & $\begin{array}{c}0.3175^{* * *} \\
(0.0176)\end{array}$ & $\begin{array}{c}0.4061 * * * \\
(0.0207)\end{array}$ & $\begin{array}{c}0.4624 * * * \\
(0.0187)\end{array}$ & $\begin{array}{l}0.522 * * * \\
(0.0201)\end{array}$ \\
\hline$\Delta$ Wind other zones & $\begin{array}{c}0.1127^{* * * *} \\
(0.0175)\end{array}$ & $\begin{array}{c}0.1641^{* * * *} \\
(0.0196)\end{array}$ & $\begin{array}{l}0.178^{* * *} \\
(0.0187)\end{array}$ & $\begin{array}{c}0.1816^{* * *} \\
(0.0166)\end{array}$ & $\begin{array}{c}0.1418 \text { *** } \\
(0.0149)\end{array}$ \\
\hline$\Delta$ Solar $_{\text {other zones }}$ & $\begin{array}{l}0.1057^{* * *} \\
(0.0069)\end{array}$ & $\begin{array}{l}0.1031^{* * *} \\
(0.0083)\end{array}$ & $\begin{array}{c}0.0985 * * * \\
(0.0086)\end{array}$ & $\begin{array}{c}0.0734^{* * *} \\
(0.0078)\end{array}$ & $\begin{array}{c}0.0877^{* * *} \\
(0.0072)\end{array}$ \\
\hline$\Delta$ Demand $_{\text {other zones }}$ & $\begin{array}{c}-0.0397^{* * *} \\
(0.0026)\end{array}$ & $\begin{array}{c}-0.0337^{* * *} \\
(0.0034)\end{array}$ & $\begin{array}{c}-0.0496^{* * *} \\
(0.0039)\end{array}$ & $\begin{array}{c}-0.062 * * * \\
(0.0035)\end{array}$ & $\begin{array}{c}-0.0735^{* * *} \\
(0.0037)\end{array}$ \\
\hline Dummies & Yes & Yes & Yes & Yes & Yes \\
\hline Observations & 8760 & 8784 & 8760 & 8760 & 8760 \\
\hline Adjusted $R^{2}$ & 0.30 & 0.19 & 0.19 & 0.23 & 0.23 \\
\hline
\end{tabular}

All the models include an intercept; standard errors in parenthesis are robust to heteroscedasticity and serial correlation. ${ }^{* * *}$ indicates $p$-value $<0.001,{ }^{* *} p$-value $<0.01,{ }^{*} p$-value $<0.05, p$-value $<0.1$.

Table A9. OLS estimation of hourly changes in net input flow of NORD; results of Equation (1).

\begin{tabular}{|c|c|c|c|c|c|}
\hline NORD & 2015 & 2016 & 2017 & 2018 & 2019 \\
\hline$\Delta$ Wind & $\begin{array}{l}-0.0609 \\
(2.4724)\end{array}$ & $\begin{array}{c}0.6564 \\
(2.5645)\end{array}$ & $\begin{array}{l}-1.7329 \\
(2.6314)\end{array}$ & $\begin{array}{c}1.9037 \\
(2.6719)\end{array}$ & $\begin{array}{c}0.0691 \\
(1.8237)\end{array}$ \\
\hline$\Delta$ Solar & $\begin{array}{c}-0.3928^{* * *} \\
(0.0302)\end{array}$ & $\begin{array}{c}-0.288^{* * *} \\
(0.0339)\end{array}$ & $\begin{array}{c}-0.5204^{* * *} \\
(0.0336)\end{array}$ & $\begin{array}{c}-0.3959 * * * \\
(0.0291)\end{array}$ & $\begin{aligned}- & 0.3584^{* * * *} \\
& (0.0285)\end{aligned}$ \\
\hline$\Delta$ Demand & $\begin{array}{c}0.2534 * * * \\
(0.0085)\end{array}$ & $\begin{array}{c}0.2074^{* * *} \\
(0.0094)\end{array}$ & $\begin{array}{c}0.2764 * * * \\
(0.0101)\end{array}$ & $\begin{array}{l}0.229 * * * \\
(0.0092)\end{array}$ & $\begin{array}{c}0.2019 \text { *** } \\
(0.0091)\end{array}$ \\
\hline$\Delta$ Wind $_{\text {other zones }}$ & $\begin{array}{c}0.2897 * * * \\
(0.0358)\end{array}$ & $\begin{array}{c}0.3054^{* * *} \\
(0.0327)\end{array}$ & $\begin{array}{l}0.311^{* * *} \\
(0.0288)\end{array}$ & $\begin{array}{c}0.3237^{* * *} \\
(0.0239)\end{array}$ & $\begin{array}{c}0.3668^{* * *} \\
(0.0223)\end{array}$ \\
\hline$\Delta$ Solar $_{\text {other zones }}$ & $\begin{array}{c}0.2032 * * * \\
(0.0195)\end{array}$ & $\begin{array}{c}0.1274^{* * *} \\
(0.0208)\end{array}$ & $\begin{array}{l}0.283^{* * *} \\
(0.0209)\end{array}$ & $\begin{array}{l}0.344^{* * *} \\
(0.0183)\end{array}$ & $\begin{array}{c}0.3548^{* * *} \\
(0.0189)\end{array}$ \\
\hline$\Delta$ Demand $_{\text {other zones }}$ & $\begin{array}{c}-0.345^{* * *} \\
(0.0114)\end{array}$ & $\begin{array}{c}-0.3345^{* * *} \\
(0.0133)\end{array}$ & $\begin{array}{c}-0.3765 * * * \\
(0.0139)\end{array}$ & $\begin{array}{c}-0.3665^{* * *} \\
(0.0129)\end{array}$ & $\begin{array}{c}-0.3415^{* * *} \\
(0.0128)\end{array}$ \\
\hline Dummies & Yes & Yes & Yes & Yes & Yes \\
\hline Observations & 8760 & 8784 & 8760 & 8760 & 8760 \\
\hline Adjusted $R^{2}$ & 0.11 & 0.18 & 0.11 & 0.12 & 0.12 \\
\hline
\end{tabular}

All the models include an intercept; standard errors in parenthesis are robust to heteroscedasticity and serial correlation. ${ }^{* * *}$ indicates $p$-value $<0.001,{ }^{* *} p$-value $<0.01,{ }^{*} p$-value $<0.05, p$-value $<0.1$.

Table A10. OLS estimation of hourly changes in net input flow of SARD; results of Equation (1).

\begin{tabular}{cccccc}
\hline SARD & $\mathbf{2 0 1 5}$ & $\mathbf{2 0 1 6}$ & $\mathbf{2 0 1 7}$ & $\mathbf{2 0 1 8}$ & $\mathbf{2 0 1 9}$ \\
\hline \multirow{2}{*}{$\Delta$ Wind } & $-0.9242^{* * *}$ & $-0.9105^{* * *}$ & $-0.8916^{* * *}$ & $-0.8558^{* * *}$ & $-0.7718^{* * *}$ \\
& $(0.0162)$ & $(0.0147)$ & $(0.0157)$ & $(0.0173)$ & $(0.0162)$ \\
\hline \multirow{2}{*}{$\Delta$ Solar } & $-0.7915^{* * * *}$ & $-0.725^{* * *}$ & $-0.6461^{* * *}$ & $-0.6912^{* * *}$ & $-0.5943^{* * *}$ \\
& $(0.0269)$ & $(0.0263)$ & $(0.0288)$ & $(0.0328)$ & $(0.0345)$ \\
\hline \multirow{2}{*}{$\Delta$ Demand } & $0.5505^{* * *}$ & $0.6917^{* * *}$ & $0.5798^{* * *}$ & $0.5093^{* * *}$ & $0.3195^{* * *}$ \\
& $(0.017)$ & $(0.0155)$ & $(0.017)$ & $(0.0162)$ & $(0.0155)$ \\
\hline \multirow{2}{*}{$\Delta$ Wind $_{\text {other zones }}$} & -0.0001 & -0.0044 & $0.0071^{* *}$ & $0.0073^{* *}$ & -0.0028 \\
& $(0.0031)$ & $(0.0029)$ & $(0.0028)$ & $(0.003)$ & $(0.0029)$ \\
\hline
\end{tabular}


Table A10. Cont.

\begin{tabular}{|c|c|c|c|c|c|}
\hline SARD & 2015 & 2016 & 2017 & 2018 & 2019 \\
\hline$\Delta$ Solar $_{\text {other zones }}$ & $\begin{array}{c}-0.0028^{* *} \\
(0.0013)\end{array}$ & $\begin{array}{c}-0.0036^{* * * *} \\
(0.0013)\end{array}$ & $\begin{array}{c}-0.0053^{* * *} \\
(0.0013)\end{array}$ & $\begin{array}{c}-0.0059 * * * \\
(0.0014)\end{array}$ & $\begin{array}{c}-0.0082^{* * *} \\
(0.0014)\end{array}$ \\
\hline$\Delta$ Demand $_{\text {other zones }}$ & $\begin{array}{l}0.002 * * * \\
(0.0005)\end{array}$ & $\begin{array}{c}0.0004 \\
(0.0004)\end{array}$ & $\begin{array}{c}0.0015^{* * *} \\
(0.0005)\end{array}$ & $\begin{array}{c}0.0024^{* * *} \\
(0.0005)\end{array}$ & $\begin{array}{c}0.0055^{* * *} \\
(0.0005)\end{array}$ \\
\hline Dummies & Yes & Yes & Yes & Yes & Yes \\
\hline Observations & 8760 & 8784 & 8760 & 8760 & 8760 \\
\hline Adjusted $R^{2}$ & 0.61 & 0.66 & 0.61 & 0.51 & 0.48 \\
\hline
\end{tabular}

All the models include an intercept; standard errors in parenthesis are robust to heteroscedasticity and serial correlation. ${ }^{* * *}$ indicates $p$-value $<0.001,{ }^{* *} p$-value $<0.01,{ }^{*} p$-value $<0.05, p$-value $<0.1$.

Table A11. OLS estimation of hourly changes in net input flow of SICI; results of Equation (1).

\begin{tabular}{cccccc}
\hline SICI & $\mathbf{2 0 1 5}$ & $\mathbf{2 0 1 6}$ & $\mathbf{2 0 1 7}$ & $\mathbf{2 0 1 8}$ & $\mathbf{2 0 1 9}$ \\
\hline \multirow{2}{*}{$\Delta$ Wind } & $-0.4463^{* * *}$ & $-0.5383^{* * *}$ & $-0.6949^{* * *}$ & $-0.7151^{* * *}$ & $-0.74^{* * *}$ \\
& $(0.0146)$ & $(0.0183)$ & $(0.0199)$ & $(0.0166)$ & $(0.0182)$ \\
\hline \multirow{2}{*}{$\Delta$ Solar } & $-0.2639^{* * * *}$ & $-0.2032^{* * *}$ & $-0.3915^{* * *}$ & $-0.5646^{* * *}$ & $\begin{array}{c}-0.5576^{* * *} \\
\end{array}$ \\
& $(0.0195)$ & $(0.0262)$ & $(0.0303)$ & $(0.0252)$ & $(0.029)$ \\
\hline \multirow{2}{*}{$\Delta$ Demand } & $0.0941^{* * *}$ & $0.111^{* * *}$ & $0.2949^{* * *}$ & $0.377^{* * *}$ & $0.3923^{* * *}$ \\
& $(0.0103)$ & $(0.013)$ & $(0.0163)$ & $(0.0145)$ & $(0.0167)$ \\
\hline \multirow{2}{*}{$\Delta$ Wind $_{\text {other zones }}$} & $0.0268^{* * * *}$ & $0.0364^{* * *}$ & $0.049^{* * *}$ & $0.0585^{* * *}$ & $0.0313^{* * *}$ \\
& $(0.0045)$ & $(0.006)$ & $(0.006)$ & $(0.0054)$ & $(0.0051)$ \\
\hline \multirow{2}{*}{$\Delta$ Solar $_{\text {other zones }}$} & $0.0083^{* * *}$ & 0.0004 & $0.0126^{* * *}$ & $0.0167^{* * *}$ & $0.0169^{* * *}$ \\
\hline \multirow{2}{*}{$\Delta$ Demand $_{\text {other zones }}$} & $(0.0018)$ & $(0.0024)$ & $(0.0027)$ & $(0.0023)$ & $(0.0026)$ \\
\hline Dummies & $-0.0082^{* * *}$ & $-0.0052^{* * *}$ & $-0.0118^{* * *}$ & $-0.0109^{* * *}$ & $-0.0096^{* * *}$ \\
\hline Observations $^{* * 0007)}$ & $(0.0009)$ & $(0.0011)$ & $(0.001)$ & $(0.0011)$ \\
\hline Adjusted $R^{2}$ & Yes & Yes & Yes & Yes & Yes \\
\hline All & 8760 & 8784 & 8760 & 8760 & 8760 \\
\hline
\end{tabular}

All the models include an intercept; standard errors in parenthesis are robust to heteroscedasticity and serial correlation. ${ }^{* * *}$ indicates $p$-value $<0.001,{ }^{* *} p$-value $<0.01, * p$-value $<0.05, p$-value $<0.1$.

Table A12. OLS estimation of hourly changes in net input flow of SUD; results of Equation (1).

\begin{tabular}{|c|c|c|c|c|c|}
\hline SUD & 2015 & 2016 & 2017 & 2018 & 2019 \\
\hline$\Delta$ Wind & $\begin{array}{c}-0.4653^{* * *} \\
(0.0241)\end{array}$ & $\begin{array}{c}-0.5463^{* * *} \\
(0.0228)\end{array}$ & $\begin{array}{c}-0.7233^{* * *} \\
(0.0204)\end{array}$ & $\begin{array}{c}-0.6626^{* * *} \\
(0.019)\end{array}$ & $\begin{aligned}-0.6831^{* * *} & (0.0167)\end{aligned}$ \\
\hline$\Delta$ Solar & $\begin{array}{c}-0.3889 * * * \\
(0.0233)\end{array}$ & $\begin{array}{c}-0.3753^{* * *} \\
(0.0217)\end{array}$ & $\begin{array}{c}-0.4072 \text { *** } \\
(0.0228)\end{array}$ & $\begin{array}{c}-0.4345^{* * *} \\
(0.0214)\end{array}$ & $\begin{array}{c}-0.4228^{* * *} \\
(0.0231)\end{array}$ \\
\hline$\Delta$ Demand & $\begin{array}{c}0.1062^{* * *} \\
(0.0158)\end{array}$ & $\begin{array}{c}0.1508^{* * *} \\
(0.0171)\end{array}$ & $\begin{array}{c}0.0914^{* * *} \\
(0.0206)\end{array}$ & $\begin{array}{c}0.1241^{* * *} \\
(0.0184)\end{array}$ & $\begin{array}{l}-0.0142 \\
(0.0233)\end{array}$ \\
\hline$\Delta$ Wind $_{\text {other zones }}$ & $\begin{array}{c}0.1663 * * * \\
(0.0307)\end{array}$ & $\begin{array}{c}0.1517 \text { *** } \\
(0.0289)\end{array}$ & $\begin{array}{c}0.2248^{* * *} \\
(0.028)\end{array}$ & $\begin{array}{c}0.2641^{* * *} \\
(0.0248)\end{array}$ & $\begin{array}{c}0.2567^{* * *} \\
(0.0251)\end{array}$ \\
\hline$\Delta$ Solar $_{\text {other zones }}$ & $\begin{array}{c}0.0571^{* * *} \\
(0.0074)\end{array}$ & $\begin{array}{c}0.0238^{* * *} \\
(0.0073)\end{array}$ & $\begin{array}{c}0.0329 * * * \\
(0.0072)\end{array}$ & $\begin{array}{c}0.0432 * * * \\
(0.0067)\end{array}$ & $\begin{array}{c}0.0503 * * * \\
(0.007)\end{array}$ \\
\hline$\Delta$ Demand $_{\text {other zones }}$ & $\begin{array}{c}-0.0429 * * * \\
(0.0018)\end{array}$ & $\begin{array}{c}-0.0402^{* * *} \\
(0.0019)\end{array}$ & $\begin{array}{c}-0.04611^{* * *} \\
(0.0021)\end{array}$ & $\begin{array}{c}-0.0544^{* * *} \\
(0.0019)\end{array}$ & $\begin{array}{c}-0.056^{* * *} \\
(0.0023)\end{array}$ \\
\hline Dummies & Yes & Yes & Yes & Yes & Yes \\
\hline Observations & 8760 & 8784 & 8760 & 8760 & 8760 \\
\hline Adjusted $R^{2}$ & 0.18 & 0.20 & 0.29 & 0.31 & 0.38 \\
\hline
\end{tabular}

All the models include an intercept; standard errors in parenthesis are robust to heteroscedasticity and serial correlation. ${ }^{* * *}$ indicates $p$-value $<0.001,{ }^{* *} p$-value $<0.01,{ }^{*} p$-value $<0.05, p$-value $<0.1$. 


\section{CNOR}

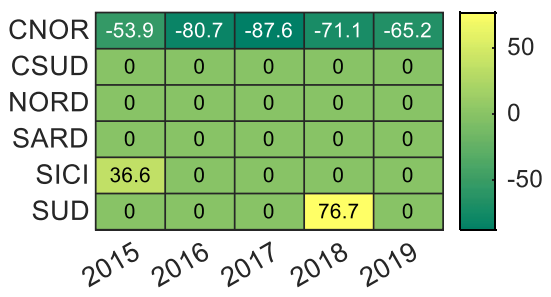

NORD

\begin{tabular}{|c|c|c|c|c|c|c|}
\hline CNOR & 0 & 0 & 0 & 0 & 0 & 1 \\
\hline CSUD & 0 & 0 & 0 & 0 & 0 & 0.5 \\
\hline NORD & 0 & 0 & 0 & 0 & 0 & \\
\hline SARD & 0 & 0 & 0 & 0 & 0 & 0 \\
\hline $\mathrm{SICl}$ & 0 & 0 & 0 & 0 & 0 & -0.5 \\
\hline SUD & 0 & 0 & 0 & 0 & 0 & \\
\hline
\end{tabular}

SICI

\begin{tabular}{|c|c|c|c|c|c|c|}
\hline \multirow[b]{2}{*}{ CNOR } & & \\
\hline & 0 & 4.9 & 6.5 & 5.3 & 3.3 & \\
\hline CSUD & 8.1 & 9.7 & \begin{tabular}{|l|}
13.5 \\
\end{tabular} & 21.6 & 18.4 & U \\
\hline NORD & 0 & 0 & 0 & 0 & 0 & 0 \\
\hline SARD & 0 & 0 & 0 & 0 & 0 & -20 \\
\hline $\mathrm{SICl}$ & \begin{tabular}{|l|}
-44.6 \\
\end{tabular} & \begin{tabular}{|l|} 
\\
\end{tabular} & \begin{tabular}{|l|}
-69.5 \\
\end{tabular} & -71.5 & -74 & -40 \\
\hline SUD & \begin{tabular}{|l|}
25.6 \\
\end{tabular} & \begin{tabular}{|l|}
17.6 \\
\end{tabular} & 27.6 & 32 & 41.8 & -60 \\
\hline
\end{tabular}

\section{CSUD}

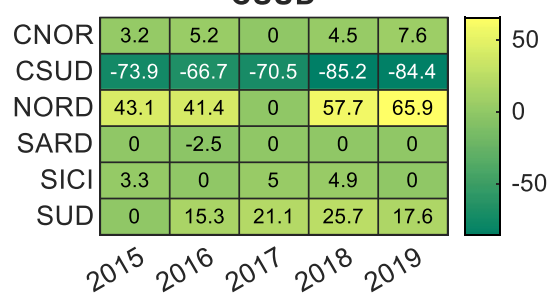

SARD

\begin{tabular}{|c|c|c|c|c|c|}
\hline CNOR & 10.2 & 8.3 & 9.5 & 5.4 & 0 \\
\hline CSUD & 15.2 & 16.8 & \begin{tabular}{|l|}
25.1 \\
\end{tabular} & 0 & 18.9 \\
\hline NORD & 39.3 & 31.6 & 0 & 34.7 & 0 \\
\hline SARD & -92.4 & -91 & \begin{tabular}{|l|}
-89.2 \\
\end{tabular} & -85.6 & -77.2 \\
\hline $\mathrm{SICl}$ & 0 & 11 & 14.2 & 14.5 & 10.3 \\
\hline SUD & 14.7 & 0 & \begin{tabular}{|l|}
12.7 \\
\end{tabular} & 11.5 & 0 \\
\hline
\end{tabular}

SUD

\begin{tabular}{|c|c|c|c|c|c|}
\hline CNOR & 2.4 & 2.3 & 2.1 & 2.2 & 5.7 \\
\hline CSUD & \begin{tabular}{|l|}
12.1 \\
\end{tabular} & 18.4 & 18.5 & \begin{tabular}{|l|l|}
18.2 \\
\end{tabular} & \begin{tabular}{|l|}
13.2 \\
\end{tabular} \\
\hline NORD & 31 & \begin{tabular}{|l|}
33.6 \\
\end{tabular} & 42 & \begin{tabular}{|l|l|}
34.2 \\
\end{tabular} & \begin{tabular}{|l|}
40.1 \\
\end{tabular} \\
\hline SARD & 0 & 0 & 1 & 0.9 & 0 \\
\hline $\mathrm{SICl}$ & 2.2 & 3.3 & 3.6 & 4.9 & 2.9 \\
\hline SUD & -46.5 & $\mid-54.6$ & 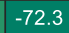 & $\mid-66.3$ & \begin{tabular}{|l|}
-68.3 \\
\end{tabular} \\
\hline
\end{tabular}

Figure A1. Heatmap chart of the impact of $100 \mathrm{MWh}$ increases in wind generation on the net input flow (MW); results of Equations (1) and (2).

\section{CNOR}

\begin{tabular}{|c|c|c|c|c|c|c|}
\hline CNOR & -92.2 & -72.9 & -80.2 & -78.2 & -77. & 40 \\
\hline CSUD & 0 & 0 & 0 & 0 & 0 & 20 \\
\hline NORD & 26.5 & 0 & 45 & 27.7 & 32.3 & \\
\hline SARD & 0 & 1.5 & 0 & 0 & 0 & -40 \\
\hline $\mathrm{SICl}$ & 0 & 0 & 4.9 & 6.2 & \begin{tabular}{|l|l} 
\\
\end{tabular} & -60 \\
\hline SUD & 0 & 0 & 0 & 0 & 0 & -80 \\
\hline
\end{tabular}

NORD

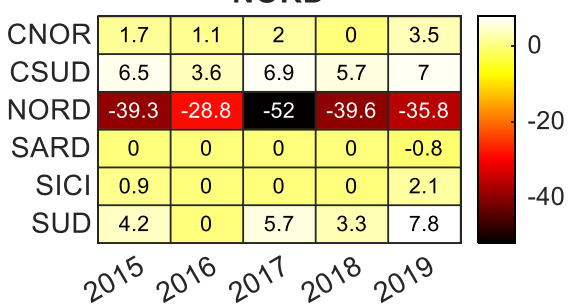

SICI

\begin{tabular}{|c|c|c|c|c|c|}
\hline CNOR & \begin{tabular}{|l|}
13.8 \\
\end{tabular} & 0 & 0 & 8.4 & 0 \\
\hline CSUD & 20.2 & 25.9 & \begin{tabular}{|l|}
19.8 \\
\end{tabular} & 0 & 31.1 \\
\hline NORD & 0 & 0 & 31.3 & 46.9 & 24.2 \\
\hline SARD & 0 & -2.6 & 0 & -3 & -3.6 \\
\hline $\mathrm{SICl}$ & -26.4 & -20.3 & -39.1 & -56.5 & $-55 . \varepsilon$ \\
\hline SUD & 27.8 & 0 & 15.4 & \begin{tabular}{|l|l}
10.6 \\
\end{tabular} & 0 \\
\hline
\end{tabular}

\section{CSUD}

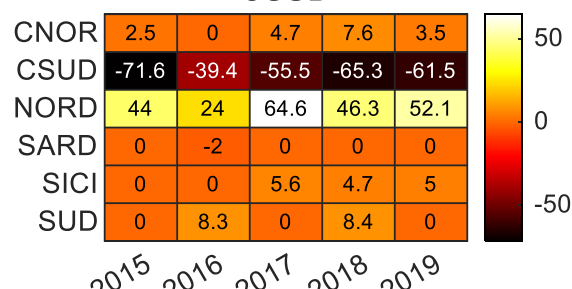

\section{SARD}

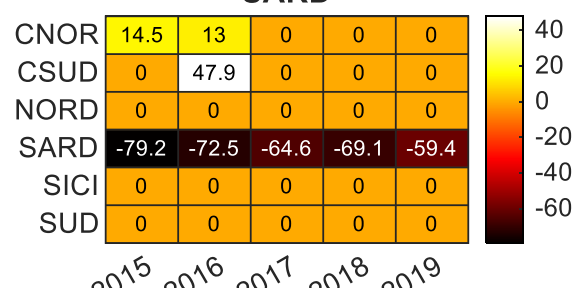

SUD

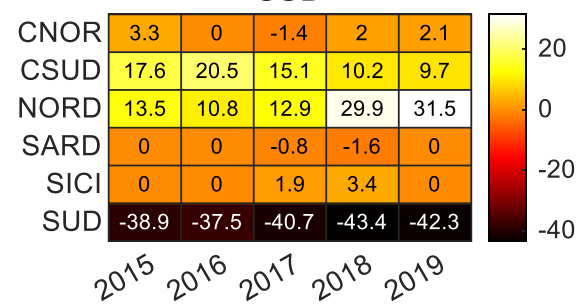

Figure A2. Heatmap chart of the impact of $100 \mathrm{MWh}$ increases in solar generation on the net input flow (MW); results of Equations (1) and (2). 
Table A13. OLS estimation of daily changes in electricity prices of CNOR; results of Equation (3).

\begin{tabular}{cccccc}
\hline CNOR & $\mathbf{2 0 1 5}$ & $\mathbf{2 0 1 6}$ & $\mathbf{2 0 1 7}$ & $\mathbf{2 0 1 8}$ & $\mathbf{2 0 1 9}$ \\
\hline \multirow{2}{*}{$\Delta$ Wind } & $-0.1081^{* * *}$ & $-0.0421^{* * *}$ & $-0.0494^{* * *}$ & $-0.0552^{* * *}$ & $\begin{array}{c}-0.0523^{* * *} \\
\end{array}$ \\
& $(0.0205)$ & $(0.0135)$ & $(0.018)$ & $(0.0143)$ & $(0.0103)$ \\
\hline \multirow{2}{*}{$\Delta$ Solar } & $-0.0134^{* * *}$ & $-0.0104^{* * *}$ & $-0.0115^{* *}$ & $-0.0141^{* * *}$ & $-0.0073^{* *}$ \\
& $(0.0048)$ & $\left(0.0037^{* *}\right.$ & $(0.0052)$ & $(0.0036)$ & $(0.0033)$ \\
\hline \multirow{2}{*}{$\Delta$ Demand } & $0.0154^{* * *}$ & $0.0124^{* * *}$ & $0.0148^{* * *}$ & $0.012^{* * *}$ & $0.008^{* * *}$ \\
& $(0.0022)$ & $(0.0014)$ & $(0.002)$ & $(0.0012)$ & $(0.0009)$ \\
\hline \multirow{2}{*}{$\Delta$ NetIn } & $-0.0066^{* *}$ & $-0.007^{* * *}$ & $-0.0068^{* * *}$ & $-0.0064^{* * *}$ & 0.0013 \\
& $(0.0028)$ & $(0.0019)$ & $(0.0023)$ & $(0.0016)$ & $(0.0013)$ \\
\hline \multirow{2}{*}{$\Delta$ NetIn other zones $^{*}$} & $-0.0008^{* * *}$ & $-0.0007^{* * *}$ & -0.0001 & -0.0002 & -0.0001 \\
\hline \multirow{2}{*}{$\Delta$ NGPrice } & $(0.0003)$ & $(0.0002)$ & $(0.0003)$ & $(0.0002)$ & $(0.0003)$ \\
\hline Dummies & 0.3156 & $0.4129^{* * *}$ & $1.1197^{* * *}$ & $1.3786^{* * *}$ & $0.6375^{*}$ \\
\hline Observations & $(0.6552)$ & $(0.1924)$ & $(0.2007)$ & $(0.1415)$ & $(0.3332)$ \\
\hline Adjusted $R^{2}$ & Yes & Yes & Yes & Yes & Yes \\
\hline All & 365 & 366 & 365 & 365 & 365 \\
\hline
\end{tabular}

All the models include an intercept; standard errors in parenthesis are robust to heteroscedasticity and serial correlation. ${ }^{* * *}$ indicates $p$-value $<0.001,{ }^{* *} p$-value $<0.01,{ }^{*} p$-value $<0.05, p$-value $<0.1$.

Table A14. OLS estimation of daily changes in electricity prices of CSUD; results of Equation (3).

\begin{tabular}{|c|c|c|c|c|c|}
\hline CSUD & 2015 & 2016 & 2017 & 2018 & 2019 \\
\hline$\Delta$ Wind & $\begin{array}{c}-0.0137^{* * *} \\
(0.0013)\end{array}$ & $\begin{array}{c}-0.0081^{* * *} \\
(0.0008)\end{array}$ & $\begin{array}{c}-0.0111^{* * *} \\
(0.0012)\end{array}$ & $\begin{array}{c}-0.0076^{* * *} \\
(0.001)\end{array}$ & $\begin{array}{c}-0.0093^{* * *} \\
(0.0009)\end{array}$ \\
\hline$\Delta$ Solar & $\begin{array}{c}-0.0092 * * * \\
(0.0031)\end{array}$ & $\begin{array}{c}-0.0046^{* *} \\
(0.0021)\end{array}$ & $\begin{array}{c}-0.0107^{* * *} \\
(0.0033)\end{array}$ & $\begin{array}{c}-0.0056^{* *} \\
(0.0024)\end{array}$ & $\begin{array}{c}-0.0042 * \\
(0.0023)\end{array}$ \\
\hline$\Delta$ Demand & $\begin{array}{l}0.01 * * * \\
(0.0009)\end{array}$ & $\begin{array}{c}0.0065^{* * * *} \\
(0.0006)\end{array}$ & $\begin{array}{c}0.0074^{* * *} \\
(0.0009)\end{array}$ & $\begin{array}{c}0.0064^{* * *} \\
(0.0007)\end{array}$ & $\begin{array}{l}0.008^{* * *} \\
(0.0007)\end{array}$ \\
\hline$\Delta$ NetIn & $\begin{array}{c}-0.0044^{* * *} \\
\quad(0.001)\end{array}$ & $\begin{array}{c}-0.0026^{* * *} \\
(0.0007)\end{array}$ & $\begin{array}{c}0.0004 \\
(0.0008)\end{array}$ & $\begin{array}{l}-0.0001 \\
(0.0006)\end{array}$ & $\begin{array}{l}-0.0001 \\
(0.0007)\end{array}$ \\
\hline$\Delta$ NetIn $n_{\text {other zones }}$ & $\begin{array}{l}-0.0002 \\
(0.0003)\end{array}$ & $\begin{array}{c}-0.0006^{* * *} \\
(0.0002)\end{array}$ & $\begin{array}{l}-0.0003 \\
(0.0003)\end{array}$ & $\begin{array}{c}0.0003 \\
(0.0003)\end{array}$ & $\begin{array}{c}0 \\
(0.0003)\end{array}$ \\
\hline$\triangle N G P r i c e$ & $\begin{array}{c}0.2792 \\
(0.6128)\end{array}$ & $\begin{array}{c}0.2395 \\
(0.1759)\end{array}$ & $\begin{array}{c}1.3375^{* * *} \\
(0.1917)\end{array}$ & $\begin{array}{c}1.1819 * * * \\
(0.1411)\end{array}$ & $\begin{array}{c}0.6796^{*} \\
(0.346)\end{array}$ \\
\hline Dummies & Yes & Yes & Yes & Yes & Yes \\
\hline Observations & 365 & 366 & 365 & 365 & 365 \\
\hline Adjusted $R^{2}$ & 0.47 & 0.43 & 0.44 & 0.44 & 0.46 \\
\hline
\end{tabular}

All the models include an intercept; standard errors in parenthesis are robust to heteroscedasticity and serial correlation. ${ }^{* * *}$ indicates $p$-value $<0.001,{ }^{* *} p$-value $<0.01,{ }^{*} p$-value $<0.05, p$-value $<0.1$.

Table A15. OLS estimation of daily changes in electricity prices of NORD; results of Equation (3).

\begin{tabular}{cccccc}
\hline NORD & $\mathbf{2 0 1 5}$ & $\mathbf{2 0 1 6}$ & $\mathbf{2 0 1 7}$ & $\mathbf{2 0 1 8}$ & 2019 \\
\hline \multirow{2}{*}{$\Delta$ Wind } & -0.0551 & -0.0047 & 0.0208 & -0.063 & -0.0235 \\
& $(0.0237)$ & $(0.0446)$ & $(0.0645)$ & $(0.0617)$ & $(0.0293)$ \\
\hline \multirow{2}{*}{$\Delta$ Solar } & $-0.002^{*}$ & $-0.0016^{*}$ & -0.0005 & $-0.0034^{* * *}$ & $-0.0026^{* * *}$ \\
& $(0.0011)$ & $(0.001)$ & $(0.0014)$ & $(0.0011)$ & $(0.0008)$ \\
\hline \multirow{2}{*}{$\Delta$ Demand } & $0.0023^{* * *}$ & $0.0019^{* * *}$ & $0.002^{* * *}$ & $0.0016^{* * *}$ & $0.0018^{* * *}$ \\
& $(0.0001)$ & $(0.0001)$ & $(0.0002)$ & $(0.0001)$ & $(0.0001)$ \\
\hline \multirow{2}{*}{$\Delta$ NetIn } & $-0.0025^{* * *}$ & $-0.0022^{* * *}$ & $-0.0018^{* * *}$ & $-0.0013^{* * *}$ & $-0.0015^{* * *}$ \\
& $(0.0003)$ & $(0.0002)$ & $(0.0004)$ & $(0.0003)$ & $(0.0003)$ \\
\hline
\end{tabular}


Table A15. Cont.

\begin{tabular}{cccccc}
\hline NORD & $\mathbf{2 0 1 5}$ & $\mathbf{2 0 1 6}$ & $\mathbf{2 0 1 7}$ & $\mathbf{2 0 1 8}$ & $\mathbf{2 0 1 9}$ \\
\hline \multirow{2}{*}{$\Delta$ NetIn $_{\text {other zones }}$} & $-0.0012^{*}$ & -0.0001 & 0.0011 & 0 & $0.0009^{* *}$ \\
& $(0.0006)$ & $(0.0005)$ & $(0.0007)$ & $(0.0005)$ & $(0.0004)$ \\
\hline \multirow{2}{*}{$\Delta$ NGPrice } & 0.2075 & 0.2375 & $1.2082^{* * *}$ & $1.2649^{* * *}$ & 0.4735 \\
& $(0.5492)$ & $(0.1802)$ & $(0.1944)$ & $(0.1373)$ & $(0.2933)$ \\
\hline Dummies & Yes & Yes & Yes & Yes & Yes \\
\hline Observations & 365 & 366 & 365 & 365 & 365 \\
\hline Adjusted $R^{2}$ & 0.52 & 0.57 & 0.48 & 0.53 & 0.58
\end{tabular}

All the models include an intercept; standard errors in parenthesis are robust to heteroscedasticity and serial correlation. ${ }^{* * *}$ indicates $p$-value $<0.001,{ }^{* *} p$-value $<0.01,{ }^{*} p$-value $<0.05, p$-value $<0.1$.

Table A16. OLS estimation of daily changes in electricity prices of SARD; results of Equation (3).

\begin{tabular}{cccccc}
\hline SARD & $\mathbf{2 0 1 5}$ & $\mathbf{2 0 1 6}$ & $\mathbf{2 0 1 7}$ & $\mathbf{2 0 1 8}$ & $\mathbf{2 0 1 9}$ \\
\hline \multirow{2}{*}{$\Delta$ Wind } & $-0.0175^{* * *}$ & -0.005 & $-0.0153^{* * *}$ & $-0.0076^{* *}$ & $-0.01^{* * *}$ \\
& $(0.0039)$ & $(0.0032)$ & $(0.0043)$ & $(0.0034)$ & $(0.0028)$ \\
\hline \multirow{2}{*}{$\Delta$ Solar } & $-0.0263^{*}$ & -0.0136 & $-0.0538^{* * *}$ & 0.0024 & $-0.0699^{* * *}$ \\
& $(0.0144)$ & $(0.0118)$ & $(0.0173)$ & $(0.016)$ & $(0.0167)$ \\
\hline \multirow{2}{*}{$\Delta$ Demand } & $0.068^{* * *}$ & $0.0495^{* * *}$ & $0.0364^{* * *}$ & $0.0213^{* * *}$ & $0.0128^{* * *}$ \\
& $(0.0097)$ & $(0.006)$ & $(0.0078)$ & $(0.0045)$ & $(0.0033)$ \\
\hline \multirow{2}{*}{$\Delta$ NetIn } & $-0.0087^{* *}$ & 0.0035 & -0.0041 & 0.0017 & 0.004 \\
& $(0.0038)$ & $(0.0032)$ & $(0.0046)$ & $(0.0033)$ & $(0.0028)$ \\
\hline \multirow{2}{*}{$\Delta$ NetIn $n_{\text {other zones }}^{* * * *}$} & $0.0007^{* *}$ & $-0.0003^{*}$ & $0.001^{* * *}$ & $0.001^{* * *}$ & $0.0017^{* * *}$ \\
\hline \multirow{2}{*}{$\Delta$ NGPrice } & $(0.0003)$ & $(0.0002)$ & $(0.0003)$ & $(0.0003)$ & $(0.0003)$ \\
\hline Dummies & 0.439 & 0.2303 & $1.3876^{* * *}$ & $1.3613^{* * *}$ & 0.2344 \\
\hline Observations & $(0.7204)$ & $(0.2018)$ & $(0.224)$ & $(0.1634)$ & $(0.4352)$ \\
\hline Adjusted $R^{2}$ & Yes & Yes & Yes & Yes & Yes \\
\hline All & 365 & 366 & 365 & 365 & 365 \\
\hline
\end{tabular}

All the models include an intercept; standard errors in parenthesis are robust to heteroscedasticity and serial correlation. ${ }^{* * *}$ indicates $p$-value $<0.001,{ }^{* *} p$-value $<0.01,{ }^{*} p$-value $<0.05, p$-value $<0.1$.

Table A17. OLS estimation of daily changes in electricity prices of SICI; results of Equation (3).

\begin{tabular}{|c|c|c|c|c|c|}
\hline SICI & 2015 & 2016 & 2017 & 2018 & 2019 \\
\hline$\Delta$ Wind & $\begin{array}{c}-0.0206^{* * *} \\
(0.0018)\end{array}$ & $\begin{array}{c}-0.0196^{* * *} \\
(0.0011)\end{array}$ & $\begin{array}{c}-0.0293^{* * *} \\
(0.0016)\end{array}$ & $\begin{array}{c}-0.0357^{* * *} \\
(0.002)\end{array}$ & $\begin{array}{c}-0.0497^{* * *} \\
(0.0025)\end{array}$ \\
\hline$\Delta$ Solar & $\begin{array}{c}-0.0242 * * * \\
(0.0082)\end{array}$ & $\begin{array}{c}-0.0223 * * * \\
(0.0057)\end{array}$ & $\begin{array}{c}-0.0163 * \\
(0.009)\end{array}$ & $\begin{array}{c}-0.0239 * * * \\
(0.0088)\end{array}$ & $\begin{array}{c}-0.036^{* * *} \\
(0.0105)\end{array}$ \\
\hline$\Delta$ Demand & $\begin{array}{l}0.0079 * * \\
(0.0033)\end{array}$ & $\begin{array}{c}0.0162^{* * *} \\
(0.0021)\end{array}$ & $\begin{array}{l}0.034^{* * *} \\
(0.0031)\end{array}$ & $\begin{array}{c}0.0353^{* * *} \\
(0.0038)\end{array}$ & $\begin{array}{c}0.0567^{* * *} \\
(0.0041)\end{array}$ \\
\hline$\Delta$ NetIn & $\begin{array}{c}0.0021 \\
(0.0051)\end{array}$ & $\begin{array}{l}-0.018^{* * *} \\
(0.0019)\end{array}$ & $\begin{array}{c}-0.0228^{* * *} \\
(0.0024)\end{array}$ & $\begin{array}{c}-0.0271 * * * \\
(0.003)\end{array}$ & $\begin{array}{c}-0.037 * * * \\
(0.0036)\end{array}$ \\
\hline$\Delta$ NetIn $n_{\text {other zones }}$ & $\begin{array}{l}0.0007^{* *} \\
(0.0003)\end{array}$ & $\begin{array}{l}-0.0003 \\
(0.0002)\end{array}$ & $\begin{array}{l}-0.0001 \\
(0.0003)\end{array}$ & $\begin{array}{l}0.001 * * * \\
(0.0004)\end{array}$ & $\begin{array}{c}0.0002 \\
(0.0005)\end{array}$ \\
\hline$\triangle N G P r i c e$ & $\begin{array}{c}1.0011 \\
(0.6794)\end{array}$ & $\begin{array}{c}-0.4207 * * \\
(0.19)\end{array}$ & $\begin{array}{c}0.6942 * * * \\
(0.2041)\end{array}$ & $\begin{array}{c}0.9578 * * * \\
(0.2161)\end{array}$ & $\begin{array}{c}-0.28 \\
(0.6208)\end{array}$ \\
\hline Dummies & Yes & Yes & Yes & Yes & Yes \\
\hline Observations & 365 & 366 & 365 & 365 & 365 \\
\hline Adjusted $R^{2}$ & 0.41 & 0.42 & 0.57 & 0.56 & 0.63 \\
\hline
\end{tabular}

All the models include an intercept; standard errors in parenthesis are robust to heteroscedasticity and serial correlation. ${ }^{* * *}$ indicates $p$-value $<0.001,{ }^{* *} p$-value $<0.01,{ }^{*} p$-value $<0.05, p$-value $<0.1$. 
Table A18. OLS estimation of daily changes in electricity prices of SUD; results of Equation (3).

\begin{tabular}{cccccc}
\hline SUD & $\mathbf{2 0 1 5}$ & $\mathbf{2 0 1 6}$ & $\mathbf{2 0 1 7}$ & $\mathbf{2 0 1 8}$ & $\mathbf{2 0 1 9}$ \\
\hline \multirow{2}{*}{$\Delta$ Wind } & $-0.008^{* * *}$ & $-0.0056^{* * *}$ & $-0.0055^{* * *}$ & $-0.0057^{* * *}$ & $\begin{array}{c}-0.0077^{* * *} \\
\end{array}$ \\
& $(0.0006)$ & $(0.0004)$ & $(0.0005)$ & $(0.0005)$ & $(0.0005)$ \\
\hline \multirow{2}{*}{$\Delta$ Solar } & $-0.0052^{* * *}$ & $-0.0029^{* * *}$ & -0.003 & $-0.0039^{*}$ & $-0.002^{*}$ \\
& $(0.0024)$ & $(0.0014)$ & $(0.0025)$ & $(0.002)$ & $(0.0025)$ \\
\hline \multirow{2}{*}{$\Delta$ Demand } & $0.0122^{* * *}$ & $0.0072^{* * *}$ & $0.0074^{* * *}$ & $0.0077^{* * *}$ & $0.0126^{* * *}$ \\
& $(0.0017)$ & $(0.001)$ & $(0.0015)$ & $(0.0013)$ & $(0.0015)$ \\
\hline \multirow{2}{*}{$\Delta$ NetIn } & -0.0007 & $-0.0024^{* * *}$ & -0.0005 & -0.0009 & $-0.0031^{* * *}$ \\
& $(0.0009)$ & $(0.0006)$ & $(0.0008)$ & $(0.0007)$ & $(0.0009)$ \\
\hline \multirow{2}{*}{$\Delta$ NetIn $n_{\text {other zones }}$} & 0.0003 & $-0.0003^{*}$ & $0.0005^{*}$ & $0.0013 * * *$ & 0.0003 \\
\hline \multirow{2}{*}{$\Delta$ NGPrice } & $(0.0003)$ & $(0.0002)$ & $(0.0003)$ & $(0.0002)$ & $(0.0003)$ \\
\hline Dummies & 0.5596 & -0.0713 & $1.2589 * * *$ & $1.03 * * *$ & 0.5423 \\
\hline Observations & $(0.6498)$ & $(0.1631)$ & $(0.1654)$ & $(0.1367)$ & $(0.4103)$ \\
\hline Adjusted $R^{2}$ & Yes & Yes & Yes & Yes & Yes \\
\hline All & 365 & 366 & 365 & 365 & 365 \\
\hline
\end{tabular}

All the models include an intercept; standard errors in parenthesis are robust to heteroscedasticity and serial correlation. ${ }^{* * *}$ indicates $p$-value $<0.001,{ }^{* *} p$-value $<0.01, *{ }^{*} p$-value $<0.05, p$-value $<0.1$.

\section{References}

1. Union, E. Directive 2009/28/EC of the European Parliament and of the Council of 23 April 2009 on the promotion of the use of energy from renewable sources and amending and subsequently repealing Directives 2001/77/EC and 2003/30/EC. Off. J. Eur. Union 2009, 5, 2009.

2. Contaldi, M.; Gracceva, F.; Tosato, G. Evaluation of green-certificates policies using the MARKAL-MACRO-Italy model. Energy Policy 2007, 35, 797-808. [CrossRef]

3. Di Dio, V.; Favuzza, S.; La Cascia, D.; Massaro, F.; Zizzo, G. Critical assessment of support for the evolution of photovoltaics and feed-in tariff(s) in Italy. Sustain. Energy Technol. Assess. 2015, 9, 95-104. [CrossRef]

4. GME-Gestore dei Mercati Energetici SpA. Available online: https:/ / www.mercatoelettrico.org (accessed on 10 December 2020).

5. Rintamäki, T.; Siddiqui, A.S.; Salo, A. Does renewable energy generation decrease the volatility of electricity prices? An analysis of Denmark and Germany. Energy Econ. 2017, 62, 270-282. [CrossRef]

6. Deane, P.; Collins, S.; Gallachóir, B.Ó.; Eid, C.; Hartel, R.; Keles, D.; Fichtner, W. Quantifying the" merit-order" effect in European electricity markets. INSIGHT-E Rapid Response Energy Brief. 2015, 4. [CrossRef]

7. Macedo, D.P.; Marques, A.C.; Damette, O. The Merit-Order Effect on the Swedish bidding zone with the highest electricity flow in the Elspot market. Energy Econ. 2021, 102, 105465. [CrossRef]

8. Clò, S.; Cataldi, A.; Zoppoli, P. The merit-order effect in the Italian power market: The impact of solar and wind generation on national wholesale electricity prices. Energy Policy 2015, 77, 79-88. [CrossRef]

9. Loumakis, S.; Giannini, E.; Maroulis, Z. Merit Order Effect Modeling: The Case of the Hellenic Electricity Market. Energies 2019, 12, 3869. [CrossRef]

10. Gelabert, L.; Labandeira, X.; Linares, P. An ex-post analysis of the effect of renewables and cogeneration on Spanish electricity prices. Energy Econ. 2011, 33, S59-S65. [CrossRef]

11. Woo, C.-K.; Horowitz, I.; Moore, J.; Pacheco, A. The impact of wind generation on the electricity spot-market price level and variance: The Texas experience. Energy Policy 2011, 39, 3939-3944. [CrossRef]

12. Würzburg, K.; Labandeira, X.; Linares, P. Renewable generation and electricity prices: Taking stock and new evidence for Germany and Austria. Energy Econ. 2013, 40, S159-S171. [CrossRef]

13. Macedo, D.P.; Marques, A.C.; Damette, O. The impact of the integration of renewable energy sources in the electricity price formation: Is the Merit-Order Effect occurring in Portugal? Util. Policy 2020, 66, 101080. [CrossRef]

14. Cludius, J.; Hermann, H.; Matthes, F.C.; Graichen, V. The merit order effect of wind and photovoltaic electricity generation in Germany 2008-2016: Estimation and distributional implications. Energy Econ. 2014, 44, 302-313. [CrossRef]

15. Benhmad, F.; Percebois, J. Photovoltaic and wind power feed-in impact on electricity prices: The case of Germany. Energy Policy 2018, 119, 317-326. [CrossRef]

16. Nord Pool Sport. The Nordic Electricity Exchange and the Nordic Model for a Liberalized Electricity Market; Nord Pool Spot: Lysaker, Norway, 2009.

17. Unger, E.A.; Ulfarsson, G.F.; Gardarsson, S.M.; Matthiasson, T. A long-term analysis studying the effect of changes in the Nordic electricity supply on Danish and Finnish electricity prices. Econ. Anal. Policy 2017, 56, 37-50. [CrossRef] 
18. O'Mahoney, A.; Denny, E. The merit order effect of wind generation on the Irish electricity market. In Proceedings of the 30th USAEE/IAEEE North American Conference, Washington, DC, USA, 9-12 October 2011.

19. Sirin, S.M.; Yilmaz, B.N. Variable renewable energy technologies in the Turkish electricity market: Quantile regression analysis of the merit-order effect. Energy Policy 2020, 144, 111660. [CrossRef]

20. Quint, D.; Dahlke, S. The impact of wind generation on wholesale electricity market prices in the midcontinent independent system operator energy market: An empirical investigation. Energy 2019, 169, 456-466. [CrossRef]

21. Amor, M.B.; de Villemeur, E.B.; Pellat, M.; Pineau, P.-O. Influence of wind power on hourly electricity prices and GHG (greenhouse gas) emissions: Evidence that congestion matters from Ontario zonal data. Energy 2014, 66, 458-469. [CrossRef]

22. Csereklyei, Z.; Qu, S.; Ancev, T. The effect of wind and solar power generation on wholesale electricity prices in Australia. Energy Policy 2019, 131, 358-369. [CrossRef]

23. Gianfreda, A.; Parisio, L.; Pelagatti, M. The impact of RES in the Italian day-ahead and balancing markets. Energy J. 2016, 37, 161-184. [CrossRef]

24. Imani, M.H.; Bompard, E.; Colella, P.; Huang, T. Predictive methods of electricity price: An application to the Italian electricity market. In Proceedings of the 2020 IEEE International Conference on Environment and Electrical Engineering and 2020 IEEE Industrial and Commercial Power Systems Europe (EEEIC/I\&CPS Europe), Madrid, Spain, 9-12 June 2020; IEEE: Piscataway, NJ, USA, 2020; pp. 1-6.

25. ENTSO-E. Available online: https://www.entsoe.eu/ (accessed on 10 December 2020).

26. Figueiredo, N.C.; da Silva, P.P. The "Merit-order effect" of wind and solar power: Volatility and determinants. Renew. Sustain. Energy Rev. 2019, 102, 54-62. [CrossRef]

27. Pantula, S.G.; Gonzalez-Farias, G.; Fuller, W.A. A comparison of unit-root test criteria. J. Bus. Econ. Stat. 1994, 12, $449-459$.

28. Breusch, T.S.; Pagan, A.R. A simple test for heteroscedasticity and random coefficient variation. Econom. J. Econom. Soc. 1979, 47, 1287-1294. [CrossRef]

29. Newey, W.K.; West, K.D. A Simple, Positive Semi-Definite, Heteroskedasticity and Autocorrelationconsistent Covariance Matrix; National Bureau of Economic Research: Cambridge, MA, USA, 1986.

30. Zarnikau, J.; Tsai, C.H.; Woo, C.K. Determinants of the wholesale prices of energy and ancillary services in the US Midcontinent electricity market. Energy 2020, 195, 117051. [CrossRef]

31. MacKinnon, J.G. Numerical distribution functions for unit root and cointegration tests. J. Appl. Econom. 1996, 11, 601-618. [CrossRef] 